meetings will include official representatives of the Italian, Spanish, and Dominican Republic governments who have been intimately involved with preparations for the Quincentenary. The special Pier 66 room rate for the conference will be $\$ 75$ per room per night and the registration fee is $\$ 190$ which includes continental breakfasts, lunch, reception and banquet, and all supplementary material. Contact: Phileas Society, 2400 E. Las Olas Blvd., Fort Lauderdale, FL 33301 ; (305) 524-3511.

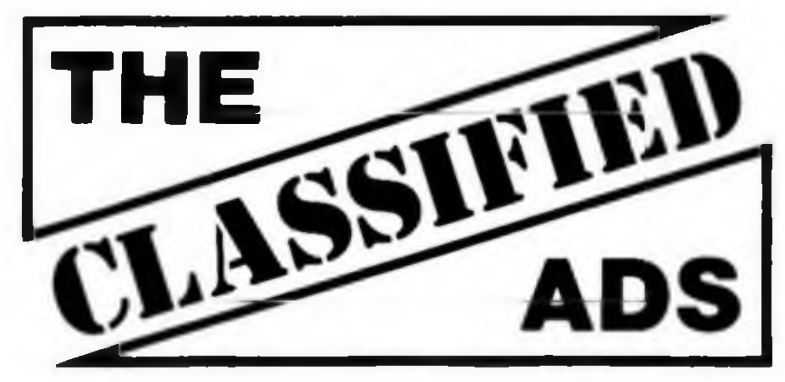

Deadlines: Orders for regular classified advertisements must reach the ACRL office on or before the second of the month preceding publication of the issue (e.g. September 2 for the October issue). Late job listings will be accepted on a space-available basis after the second of the month.

Rates: Classified advertisements are $\$ 5.25$ per line for ACRL members, $\$ 6.60$ for others. Late job notices are $\$ 12.60$ per line for members, $\$ 14.70$ for others. Organizations submitting ads will be charged according to their membership status.

Telephone: All telephone orders should be confirmed by a written order mailed to ACRL headquarters as soon as possible. Orders should be accompanied by a typewritten copy of the ad to be used in proofreading. An additional $\$ 15$ will be charged for ads taken over the phone (except late job notices or display ads).

Guidellnes: For ads which list an application deadline, that date must be no sooner than the 20th day of the month in which the notice appears (e.g., October 20 for the October issue). All job announcements should include a salary figure. Job announcements will be edited to exclude discriminatory references. Applicants should be aware that the terms faculty rank and status vary in meaning among institutions

JOBLINE: Call (312) 944-6795 for late-breaking job ads for academic and research library positions. A pre-recorded summary of positions listed with the service is revised weekly; each Friday a new tape includes all ads received by 1:00 p.m. the previous day. Each listing submitted will be carried on the recording for two weeks. The charge for each two-week listing is $\$ 30$ for ACRL members and $\$ 35$ for non-members.

Fast Job Listing Service: A special newsletter for those actively seeking positions. This service lists job postings received at ACRL headquarters four weeks before they appear in C\&RL News, as well as ads which, because of narrow deadlines, will not appear in $C \& R L$ News. The cost of a six-month subscription is $\$ 10$ for ACRL members and $\$ 15$ for non-members.

Contact: Classified Advertising Dep't, ACRL, American Library Association, 50 E. Huron St., Chicago, IL 60611; (312) 944-6780.

\section{MATERIALS WANTED}

Space Problems? We will buy your surplus serials, technical, scientific and historic materials. Send list for best offer to: Colfax Books, P.O. Box 380542, Denver, CO 80238.

\section{POSITIONS OPEN}

ACQUISITIONS AND COLLECTION DEVELOPMENT LIBRARIAN at Steenbock Library, University of Wisconsin, Madison. Steen-

\section{December}

5-8-Resource management: The Office of Management Services is offering a three and a half day program in Scottsdale, Arizona, aimed at helping library managers make sound resource decisions. Participants explore the actual and potential roles of financial management systems in improving organizational performance. Fee: \$450. Contact: see listing for October 3-6.

bock serves 33 academic departments, 11 research centers in the College of Agriculture and Life Sciences, the School of Family Resources and Consumer Sciences, and the School of Veterinary Medicine. The library is the federal depository for USDA and other selected documents. Responsibilities: coordinate collection development activities for the library's monographs, serials and documents; negotiate resource sharing activities with other campus libraries, including federal depository library selection activities; select for the government documents collection; monitor, evaluate. and produce reports on the expenditures of the acquisitions budget; contribute to reference and library instruction with emphasis on information service to government documents. Position reports to Director of Steenbock Library. Requires MLS from an ALA-accredited school; minimum of three years of professional experience in academic, research, or large public library; experience in collection development and management including knowledge of government documents. Demonstrated ability in budget management; strong oral, written, and interpersonal communication skills; ability to work closely with library staff, other campus librarians, and faculty are highly desirable. Selection of either Academic Librarian or Senior Librarian title to be based on successful candidate's credentials. Excellent benefits; salary minimum for Academic Librarian: $\$ 26,606$; Senior Librarian: $\$ 30,529$. Send letter of application, resume, names, addresses, and telephone numbers of three references to: Lois Komai, Steenbock Library, 550 Babcock Drive, University of Wisconsin-Madlson, Madison, WI 53706. Application deadline: August 31, 1989. An EEO/AA employer.

ASSISTANT ACQUISITIONS LIBRARIAN. Under the direction of the Head of Acquisitions and Collection Development: Supervises the processing of orders and receipts for all library materials formats utilizing NOTIS and OCLC. Coordinates the maintenance of records utilized in the acquisitions process. Supervises the following collection maintenance activities: binding, gifts and exchange, and replacements. Participates in collection development activities. Supervises Acquisitions Department in the absence of the Head. Teaches in the library science curriculum. Qualifications: Required: ALA accredited MLS. Preferred: Second Master's Degree. Experience with automated systems, acquisitions and/or serials, including bibliographic skills. Knowledge of various material formats and the publishing trade. Salary and Rank: $\$ 17,500$ minimum for nine months, negotiable depending on qualifications. Additional eight week summer school contract normally available. Faculty appointment at the rank of Assistant Professor in a tenure-track position. Comprehensive insurance including health, dental, and life; State retirement; tuition benefits. SMSU is the second largest public University in Missouri with over 17,000 students and the SMSU Libraries contain over one and one half million items. Apply to: Send a letter of application and resume, including the names of three references (with address and telephone number) to: Lynn Cline, Head, Acquisitions and Collection Development, Duane G. Meyer Library, 901 S. National, Box 175, Southwest Missouri State University, Springfield, MO 65804-0095. Closing Date: Applications received by July 17, 1989, will receive first consideration. Southwest Missouri State University is an equal opportunity, affirmative action employer.

ASSOCIATE LAW LIBRARIAN, for a dynamic State Law Library and Maine State Legislature's research center. Responsibilities are equally divided among cataloging, serials management, and reference duty. Seeking a candidate with experience, enthusiasm, and energy to join an interactive team of librarians (15 FTE) who share technical and public service responsibilities. MLS degree required. Current online cataloging experience required; automated systems/ serials experience necessary; reference or legal research experi- 
ence preferred. Salary starts at $\$ 29,578$; excellent benefits. Send resume and 3 references to: Lynn E. Randall, State Law Librarian, State Law and Legislative Reference Library, State House Station \#43, Augusta, ME 04333

00000000000000000000000000000 DIRECTOR ALEXANDER LIBRARY

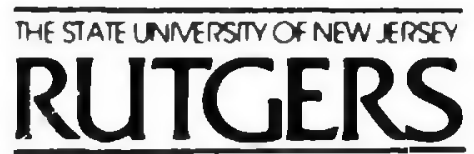

Rutgers University Libraries invite applications and nominations for the position of Director, Alexander Library and its branches. The Archibald Stevens Alexander Library is the main humanities and social sciences research library. Located on the College Avenue Campus in New Brunswick, it is the largest of the 18 libraries in the Rutgers' system and supports the Graduate School of Education, Social Work, Communication, Information and Library Studies, and the Graduate School of Arts and Sciences. The Library also services undergraduates in New Brunswick. I he branch libraries include the Art, Music, and East Asian Libraries, the Center for Urban Policy Research Library, and the Institule for Management and Labor Relations Library. The humanities and social science research libraries collections number over one million volumes; there are 70 librarians and support staff. The Director is responsible for the leadership and management of the humanities and social science libraries, including planning and administration of library programs. The Director will act as liaison to faculty and students, coordinate humanities and social science research libraries' activities with systemwide programs and represent the humanities and social science libraries and library system as a whole

Qualifications: MLS from an accredited library program (advanced humanities or social science degrea preferred). Academic/research library $\in$ :xperience with minimum five years administrative $€ x$ perierce. Should be eligible for tenured librarian status

Salary: Negotiable, dependent upon experience and qualifications; minimum $\$ 50,000$.

Please send nominations and applications no later than August 1, 1989 to:

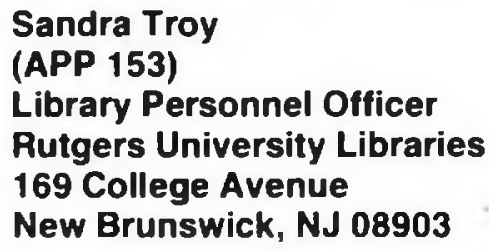

EOIAA Employer
ASSOCIATE LIBRARIAN. The Pfau Library is seeking a librarian to serve as Head of Reference. Responsible for general reference services, bibliographic instruction, computerized information service (online searching and CD-ROM), selection and management of the reference collection. ALA accredited degree and minimum five years in academic library reference work required; second master's degree in business or science preferred; experience in bibliographic instruction and database searching required. Files must be completed no later than September 1, 1989; beginning date preferred is November 1,1989 . Current salary range is $\$ 39,960-\$ 55,548$ with an increase anticipated 6-1-89. Moving expenses may be provided Submit a letter of application no later than August 1, 1989 to: Coordinator, Library Recruiting Committee, Pfau Library, California State University, San Bernardino, 5500 University Parkway, San Bernardino, CA 92407-2347. California State University, San Bernardino is an Equal Opportunity, Affirmative Action, Section 504 Title IX employer.

CATALOG LIBRARIAN, Stanford University Libraries. The Stanford University Libraries is seeking a Cataloger for a fixed term position (18 months with possibility of extension) to provide original cataloging to Judaica titles from the library of Professor Salo Wittemeyer Baron. Responsibitities include original cataloging of Judaica in the monograph and serial format, including antiquarian titles; with a strong emphasis on titles in Hebrew, but including titles in Yiddish and other European languages. Requirements: MLS or equivalent strong knowledge of Hebrew; ability to do detailed work accurately and to maintain a high level of productivity; flexibility and ability to work cooperatively with others. Qualifications: Reading knowledge of Yiddish and at least one other European language; cataloging ex perience using AACR2, BDRB, LC rule interpretations, LC romanization of Hebrew and Yiddish. Assistant/Associate Librarian with initial salary range of $\$ 27,000-\$ 41,400$ depending upon qualifications and experience. Send letter of application, statement of qualifications, resume, and names and addresses of three references by August 31, 1989 to: Irene Yeh, Acting Librarian Personnel Officer, Stanford University Libraries, Stanford, CA 94305-6004. Cite \#907-CRL on all correspondence. EOE/AAE. Full vacancy listing available upon request.

CATALOG LIBRARIAN. The University of Arizona Library is seeking a librarian to be responsible for the original cataloging of monographs in English, French, German, and Italian literatures and languages. The classics, linguistics, religion, and philosophy are also included in the assignment. Additional responsibilities include active participation in departmental planning, membership on Library and University committees, and may include reference and collection de velopment work. Requirements include: an ALA-accredited MLS degree; knowledge of or experience with AACR2, LC classification LCSH, and OCLC or a similar utility. Applicants with previous cataloging experience and with bibliographic knowledge of European languages will be preferred. Preference will be given to women and minorities. The salary will be based upon qualifications and experience; the beginning professional salary is $\$ 20,000$. Librarians at the University of Arizona have academic professional status, are eligible for continuing status, are voting members of the faculty and may take up to 24 days professional leave per year. They have 12-month appointments with 22 days of vacation, 12 days of sick leave, and 10 holidays annually. A standard package of fringe benefits is available Applications must be received by August 15, 1989. Send letter of ap plication, resume, and the names of three references to: $W$. David Laird, University Librarian, University of Arizona Library, Tucson, AZ 85721. The University of Arizona is an equal employment opportunity employer with an affirmative action plan. Non-citizens must include current visa status.

COMPUTER REFERENCE SERVICES LIBRARIAN Under the general direction of the Associate University Librarian for Public Services, the Computer Reference Services (CRS) Librarian is responsible for coordinating the planning and implementation of computer reference services, both library-wide and at the departmental levels. The CRS Librarian serves as chair of the Computer Reference Services Advisory Committee, works closely with the Library Instruction Librarian and Systems Librarian, acts in a liaison capacity with campus users groups, serves as software specialist, provides instructional and in-service educational activities, and coordinates policy development. In addition, must be able to provide general reference service and participate in scholarly activities. The University Library is engaged in intensive efforts to more effectively reach its multicultural and multi-ethnic community. Minimum qualifications: Pos- 


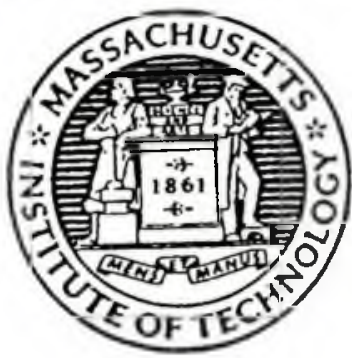

\section{ASSOCIATE DIRECTOR FOR PUBLIC SERVICES} Massachusetts Institute of Technology

This position includes primary responsibility for directing the public services activities of the MIT Libraries including administration of divisional and branch libraries, information services, literature searching, and services to outside users. Along with the Director of Libraries and three other Associate Directors (Administration, Collection Management and Technical Services, and Systems and Planning) the incumbent will participate fully in the overall administration of the library system, including long-range planning, program development and evaluation, budget formulation, and the establishment of system-wide policies.

The Associate Director for Public Services has oversight of five major subject libraries-Architecture and Planning, Engineering, Humanities, Science, and Social Sciences and Management-and their branch libraries. The heads of these libraries report to the Associate Director as does the Head of the Computerized Literature Search Service. Total public services staft include 45 professionals, 66 support staff, and 19 FTE student assistants.

Among the major new initiatives in which the Associate Director will play a primary role are an assisted self-study of information services; expanded use of CD-ROM and other technologies in reference and information services; extension of services through the campus network; and strengthening links with and services to faculty, students, and research staff.

MIT has implemented an online information system consisting of an online public access catalogue, circulation, MARC records management system, and electronic mail, using a Geac computer. A major retrospective conversion project will commence shortly. Further automation efforts will focus on authority control, acquisitions, and serials.

The Libraries' collections total over 2 million printed volumes, over 1.5 million microforms, and extensive collections of slides, photographs, sound recordings, printed music, maps, manuscripts, motion pictures and video recordings, and computer software. The total budget for FY 1989 is over $\$ 10.5$ million; the materials budget is over $\$ 2.7$ million. Total staff of 275 includes 87 professionals, 151 support staff, and 37 FTE student assistants. The MIT Libraries maintain memberships in the Boston Library Consortium, OCLC (through NELINET), and the Association of Research Libraries.

Qualifications for this position include an MLS from an ALA-accredited library school. Additional graduate work in a subject area relevant to MIT's research and teaching programs is highly desirable. Very extensive and increasingly responsible experience in public services in a research library is required. Candidates are expected to have familiarity with current issues affecting information and reference services in a university library including a thorough understanding of the applications of new and emerging technologies. Candidates should have had substantial experience in the supervision and management of public services in a library whose collections include substantial holdings in engineering and science. Candidates will be expected to demonstrate a command of issues facing research libraries today and in the near future, as well as highly developed interpersonal and analytical skills. Equally important is the ability to work effectively as a member of a senior management team in a major research library. Candidates will also be expected to demonstrate a record of leadership and achievement in the library profession.

Salary: $\$ 52,000+$ commensurate with experience and qualifications.

The MIT Libraries offers excellent benefits, including tuition assistance, a children's scholarship program, and a relocation allowance. MIT is a smoke-free campus.

Review of candidates will commence in August and continue until the position is filled. Interested candidates should send a resume and the names and addresses of five current, confidential references to:

\section{Search Committee (CRL) \\ Associate Director for Public Services \\ The Libraries, Room 14S-216 \\ Massachusetts Institute of Technology \\ Cambridge, MA 02139}




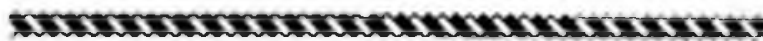

\section{CHIEF BIBLIOGRAPHER}

The University of Alabama

\section{(Search Extended)}

The University of Alabama Libraries invite applications for the position of Chief Bibliographer. This position affords the opportunity to redirect collec tion management policy and practice in an environment that is conducive to advantageous change The Chief Bibliographer reports to the Associate Dean of Libraries for Collections and Inormation Services and is responsible for planning, imple menting, monitoring, coordinating, and evaluating the collection development program in ar evolving environment. Reference and other librarians (22) are in the process of developing collection skills, activities, procedures, and policies under thie leadership of this position. Qualifications: Required: MLS from a program accredited by ALA; relevant experience in an academic library; excellent ora and written communications skills; an understanding of publishing, book trade, higher education, and budget management; knowledge of issues and trends in bibliographic control, collection assessment and collection management; experience in management of approval plans; demonstrated skill in planning, organizing, and coordinating work of others; ability to work effectively and praductively with faculty, students, and with library personnel at all levels; skill in developing, analyzing, and interpreting relevant statistical data; ability to function ef fectively in a changing environment; and evidence of professional andior scholarly activity. Preferred additional graduate degree; working knowledge of one or more foreign languages, automated sys tems, particularly in acquisitions, and familiarity with the RLG Conspectus. The University of Alabama is a member of the Association of Research Libraries and the Center for Research Libraries. Twelvemonth, tenure-earning position. Salary and rank depend on qualifications: assistant or associate professor rank, $\$ 30,000$ minimum salary, which includes an administrative stipend

Send cover letter, resume, and names and addresses of three references by August 20, 1989 to:

\section{Sondra Tucker \\ Libraries Personnel Officer \\ The University of Alabama \\ Collections Development Search \\ P.O. Box 870266}

Tuscaloosa, AL 35487-0266

The University of Alabama is an equal opportunity. affirmative action employer session of an MLS from an ALA-accredited library school; three years experience in online database searching; experience in coordination, management, or development of computer reference services; knowledge of the latest developments in computer reference service; three years professional reference experience, two of which must be in an academic library; strong interpersonal and communications skills; instructional and in-service training experience such as training searchers in using BRS, DIALOG, and CD-ROM; experience in the use and application of optical disk technology, e.g., CD-ROM; experience working with microcomputer applications. Desirable qualifications: Experience integrating new technologies into the reference environment, e.g., manipulating numeric and textual databases; experience teaching the use of microcomputer and attendant technology, e.g. , modems, printers, uploading, downloading; experience in end-user training; experience in the maintenance and management of software materials. Appointment level: Tenure-track (faculty status) position at the Senior Assistant rank with a salary range of $\$ 31,680$ to $\$ 43,896$ depending upon qualifications. Write for a detailed vacancy announcement. Application procedures: Send a letter (postmarked no later than August 4, 1989) addressing the above qualifications, a current resume, and names and addresses of three references to: Charles Martell, Dean \& University Librarian, California State University, The Library, 2000 Jed Smith Drive, Sacramento, CA 95819-2695. An equal opportunity, affirmative action institution.

CONGRESSIONAL ARCHIVIST. Manuscripts Librarian. The University of Arizona Library is seeking a Congressional Archivist who will manage and process congressional collections, maintain contact with donor offices, use computer-based systems for local and national control, supervise other processing staff, and provide reference service in the Special Collections Reading Room. The Specia Collections Department contains the Arizona and Southwestern Collections of books, photographs, manuscripts, University archives, ephemeral, and other research collections. The Special Collections staff is comprised of 4.0 professional librarians, 2.5 career staff, and student assistants. Qualifications include demonstrated success in archival processing (required). An ALA-accredited MLS and/or relevant master's degree, such as History of Political Science (strongly preferred). Preference will be given to a person with specialized training and experience in processing modern congressional collections in an academic/research library. Preferential treatment will be given to women and minorities. Minimum salary is $\$ 20,000$; higher salary is negotiable depending upon qualifications. Librarians at the University of Arizona have academic professional status, are eligible for continuing status, are voting members of the faculty, and may take up to 24 days professional leave per year. They have 22 days paid vacation, 12 days sick leave, and 10 holidays. A standard package of fringe benefits is available. Send letter of application, resume and names of three references to: $W$. David Laird, University Librarian, Universtty of Arizona Library, Tucson, AZ 85721. Applications must be postmarked by September 15,1989 . The position will be available January 1,1990 . The University of Arizona is an equal em ployment opportunity employer with an affirmative action plan. Noncitizens must include current visa status.

COORDINATOR OF AUTOMATION. Reports to the University Librarian. Responsibilities include management of Hunter Library's LS2000 opac subsystem and implementation of the circulation subsystem. Other duties include staff training in computer applications, liaison with the University Computer Center, the Western North Carolina Library Network (WNCLN) and responsibilities as a subject bibliographer. Western Carolina University and two other state universities have formed WNCLN which shares a LS2000 opac/circulation system. Terminals at WCU are connected via dedicated telephone lines to a shared minicomputer on one of the other campuses. A net work librarian is responsible for maintenance, tapeloading and telecommunications of the shared facility. In addition to LS2000, Hunter Library is employing computers in other operations and expects to expand such applications. Required: Master's degree in Library Science from an ALA-accredited library school, experience with opac and circulation online systems, at least two years experience in a library. Candidate must demonstrate an understanding of the instruction and research needs of students and faculty, possess oral and written communication skills, and have an ability to work effectively with library faculty, staff and the university community. Preferred: Knowledge of microcomputer applications in libraries. Position is twelve-month, tenure-track, choice of TIAACREF or state retirement system. Salary $\$ 25,440$ with a possible increase subject to legislative action. Send letter of application, resume, and names of three refer- 


\section{University of California, San Diego The University Library}

The Library at the University of Califomia, San Diego invites applications for three positions. The University Library consists of the Central University Library, The Biomedical and Medical Center Libraries, the Undergraduate Library, the Science and Engineering Library, the Scripps Institution of Oceanography Library, and the Graduate School of Intemational Relations and Pacific Studies Library. Collections total over 1.8 million volumes.

HEAD, PUBLIC SERVICES, Biomedical Library. Associate Librarian or Librarian rank. Under the general direction of the Biomedical Librarian, incumbent plans, develops, manages, and evaluates the $\mathrm{Bi}$ omedical Library's public services, including reference, circulation, and interlibrary loan/document delivery services. Manages staff of four librarians, six support staff, and five FTE students. Provides leadership for integrating advanced library technologies into public service functions. Assists director in policy decisions and in developing and implementing new programs. Qualifications: MLS from an ALAaccredited library school; minimum of five years' experience in a health/life sciences academic library in increasingly responsible positions; strong administrative and leadership skills, excellent communication and interpersonal skills; expertise with online searching, library instruction, and automated library systems. Preferred: Successful supervisory experience, collection development/management experience. Send applications to Mary Horres, Biomedical Librarian, c/o the address below.

PUBLIC SERVICES LIBRARIAN, International Relations and Pacific Studies Library. Assistant or Associate rank. Under the general direction of the head librarian, incumbent provides public service and functions as liaison between the IR/PS library and Central Library's technical services departments. The librarian provides general reference services, assists in library instnuction programs, does computer searching; in conjunction with other data service librarians collaborates in the creation of social science databases and other access tools. Supervises small serial maintenance operation. Other duties as assigned. Qualifications: MLS from an ALA-accredited library school and academic preparation in the social sciences, business, or relevant area studies. Demonstrated communication skills and ability to work effectively with faculty and other researchers. Highly desirable: experience/training in reference and searching of databases; working knowledge of cataloging and acquisition procedures. Desirable: reading knowledge of an east Asian language.

SOCIAL SCIENCES LIBRARIAN, Central University Library. Assistant or Associate Librarian. Under the general direction of the Associate University Librarian-Collections and the Head, Reference and Research Services, the librarian functions as the liaison between the Library and the Departments of Anthropology, Linguistics, and Psychology, and other programs and deparments as assigned. The librarian develops and manages collections; assists scholars in locating resources and designing effective search strategies; performs computer searches; provides user instruction, and performs general reference service. Other duties as assigned. Qualifications: MLS from an ALA-accredited library school; solid understanding of scholars' information needs and the organization and accessibility of the literature in the areas of responsibility; demonstrated experience and skills in collection development/management, reference and research services, online services and library instruction; excellent communication skills. Knowledge of and/or experience in the application of electronic technology to the retrieval and management of information is highly desirable. An advanced degree in a relevant area is highly desirable.

Salary range: Assistant Librarian: \$26,136 - \$33,444; Associate Librarian: \$31,944 - \$46,020; Librarian: $\$ 42,948-59,556$. Appointment at the higher rank requires progressively superior experience and qualifications. UCSD librarians are expected to participate in librarywide planning and to be active professionally. UCSD is an equal opportunity, affimative action employer. Application received by September 15 , 1989 are assured of consideration. Submit a letter of application, resume and list of references to: Janet Tait, Library Personnel Office, C-075-H-1, University of Califomia, San Diego, La Jolla, CA, 92093. 
ences to: Sharon Kimble, Search Committee, Hunter Library, Western Carolina University, Cullowhee, NC 28723. Preference will be given to applications received by September 1, 1989. Western Carolina University is one of the sixteen senior institutions of the University of North Carolina and an affirmative action, equal opportunity employer. The University is located between the Great Smoky Mountains and the Blue Ridge Mountains, 55 miles west of Asheville, North Carolina.

DEPUTY LIBRARIAN, The University of the West Indies, St. Augustine, Trinidad. Applications are invited for the following vacancy in the Medical Sciences Library: Deputy Librarian. With good degree in biological/biomedical sciences and professional qualifications in librarianship/information science. Familiarity with automated systems, extensive professional experience in Medical Sciences libraries. Knowledge of a foreign language essential. Salary: $\$ 82,536-\$ 93,984$. Pension, passages, housing, travel grant. Send applications with details of qualifications and experience naming three references to: The Campus Registrar, The University of the West Indies, St. Augustine, Trinidad, W.I., as soon as possible. Further details of posts sent to all applicants.

DIRECTOR OF PUBLIC SERVICES. The Central Michigan University Libraries are seeking a Director of Public Services who will be responsible for planning, management, and leadership of the Libraries' public services and collection development programs. Responsibility includes Access Services, Information and Research Services, audiovisual and related instructional support services, and collection development activities. Reports to the Dean of Libraries. As a member of the Libraries' senior management, the Director of Public Services will participate in the general management of the Libraries and play a key role in planning for a proposed major library addition. Required qualifications: ALA-accredited MLS; at least five years professional public services experience, at least three years of which are in academic libraries; significant supervisory experience; experience in collection development; demonstrated commitment to public services; demonstr ated skills in planning, management, leadership, oral and written communication, and interpersonal relations. Desired qualifications: additional graduate degree; experience with library automation; knowledge of instructional technology and related services; evidence of commitment to library services through a record of scholarly and/or professional participation and accomplishment. Salary commensurate with qualifications (range about $\$ 31,950$ to $\$ 52,550$ for $1989-90$ ). Excellent fringe benefits. Central Michigan University is located in Mt. Pleasant, a city of about 25,000 one hour north of Lansing. The University offers programs through the doctoral level to a campus enroltment of 17,000 students. The Libraries, with a collection of over 900,000 volumes, are implementing NOTIS and have 77 librarians and support staff. Applications will be accepted until the position is filled. Review of candidates' files will begin immediately. Submit letter of application stating this position; resume; and names, addresses, and telephone numbers of three references to: Chairperson, Selection Committee, Central Michlgan University, Park 207, Mt. Pleasant, MI 48859. CMU is an affirmative action and equal opportunity institution

DIRECTOR, TEACHING LEARNING RESOURCE CENTER. The University of Southern Mississippi Libraries include Cook Memorial Library, McCain Library and Archives, the Teaching Learning Resource Center, and Cox Library at the Gulf Coast branch campus. The library system is a member of SOLINET and utilizes the BNA online ordering system and Faxon Microlinx. The initial phases of an integrated automation system are now being installed. Director of TLRC supervises all areas and staffing of the unit including audiovisual equipment loans; learning lab for nonprint materials; audioactive laboratory for language and speech; preview, rental, and purchase of nonprint materials; Graphic Services; Music Resources Center; and Nursing Learning Center. Reports to University Librar-

\title{
1
}

\section{HEAD OF CATALOGING}

\section{The University of California, Berkeley}

The Bancroft Library at the University of California, Berkeley, is one of the largest libraries of manuscripts, rare books, and special collections in the United States. Among Bancroft's holdings are the Bancroft Collection, the Mark Twain Papers and Project, the Regional Oral History Office, and the University Archives. Bancroft's holdings include over 400,000 volumes, 54,000,000 manuscripts, 2,300,000 photographs, 67,000 microforms, and 21,000 maps

Reporting to the Coordinator of Technical Services, the Head of Cataloging oversees cataloging, authority control policy within the Bancroft Library, and the development of online bibliographic control of all Bancroft collections. Other duties include interpreting campus and Berkeley Library policy to Bancroft staff, and performing original cataloging in an area of subject expertise.

Qualifications: MLS degree from an accredited library school or equivalent; strong experience in cataloging management, preferably with both book and non-book materials using various MARC formats; demonstrated leadership within a complex library operation; commitment to staff participation in collegial management; and excellent communication skills. A strong humanities background-preferably in western American history -is desirable, as are a broad knowledge of library technical processing functions, experience in adapting an online catalog system, and reading knowledge of at least 2 foreign languages-one of which should be Spanish or Latin.

Position available October 1,1989 , or as soon thereafter as possible. Rank and salary (\$35,088-\$44,020/year) will be based on qualifications. Closing date for applications is August 1, 1989.

Apply in writing, including with your letter a complete statement of qualifications, a full resume of education and experience, and names and addresses of 3 references, to:

\author{
Janice Burrows \\ Director of Library Human Resources \\ 447 Library Annex \\ University of California \\ Berkeley, CA 94720
}


ian. Qualifications: Successful candidates must have excellent leadership, interpersonal, communication, organizational, and managerial skills. At least 5 years educational media experience in an academic library preferable. Supervisory experience and an ALAaccredited $M L S$ required. Tenure-track, 12-month position with faculty status. Minimum salary is $\$ 35,000$, dependent upon qualifications and experience. Send letter of application (noncitizens must include current visa status), resume, and names, addresses, and telephone numbers of 3 professional references to: Terry Latour, Search Committee, McCain Library and Archives, The University of Southern Mississippi, Southern Station, Box 5148, Hattiesburg, MS 39406-5148. Applications reviewed beginning July 31, 1989, and will continue until position is filled. USM is an equal opportunity, affirmative action employer. Minorities and women are encouraged to apply.

HEAD, BIBLIOGRAPHIC CONTROL. The University of MissouriColumbia Libraries is seeking qualified applicants for the position of
Head of the Bibliographic Control Department. Principal responsibilities include planning, directing, and evaluating the performance of the Department in fulfilling its responsibility of bibliographic control for library users and staff; designing and monitoring workflows and allocating and assigning staff within the Department; supervising the work assignments, workloads, training, continuing education, and performance of team leaders in the Department; participating in the continuing development of the online catalog (LUMIN) and serving on committees to identify effective use of LUMIN, enhancements to LUMIN, and to establish bibliographic standards for LUMIN; keeping up-to-date on national cataloging standards and developments, and issues facing academic research libraries in bibliographic access and automation; administering grants in the area of bibliographic control, as required; and cataloging monographs and/or serials. Requires minimum of a master's degree from an ALA-accredited program with a second subject masters degree preferred. At least five years of cataloging experience including some supervisory experience; demonstrated experience in managing cat-

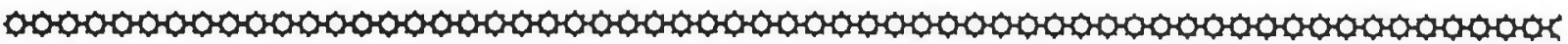

\title{
REFERENCE AND TECHNICAL SERVICES LIBRARIAN
}

\author{
Tozzer Library \\ Harvard University
}

Reporting to the Librarian of Tozzer Library, provides and coordinates reference service at a reference desk and by individual appointment to a diverse group of researchers in anthropology and related fields; develops and coordinates a program of bibliographic instruction; provides referral to relevant collections and services at other libraries; provides bibliographies and other documentation relating to Library collections and services; provides ongoing evaluation and development of the reference collection, including acquisitions and withdrawal of materials; and coordinates the exhibits program. [60\%]

Reporting to the Head of Technical Services, supervises bibliographic searching and the order process; supervises serial control; resolves complex receipt problems, including serving as liaison with vendors; monitors the acquisitions budget and participates in budget preparation; oversees the processing of gift materials; and develops an exchange program with libraries and institutions worldwide, and oversees correspondence and records of these programs. [40\%]

Qualifications: MLS degree from an ALA-accredited library school required; advanced degree in anthropology preferred; two years experience as a reference librarian in an academic library and familiarity with technical services operations preferred; proven interpersonal and communications skills, as well as ability to work effectively with students, faculty, and colleagues; supervisory experience highly desirable; reading knowledge of at least one modern European language required; experience with automated library systems highly desirable.

Rank and Salary: Librarian I or II: minimum $\$ 28,200$, dependent on qualifications.

Available: July 1, 1989.

Library Profile: Tozzer Library has one of the world's leading research collections in anthropology, covering anthropological linguistics, biological anthropology, cultural anthropology, and prehistoric archaeology. Housing approximately 171,000 volumes and 2,000 serials, the Library serves the teaching and research needs of the Anthropology Department and the Peabody Museum of Archaeology and Ethnology. The Library also supports a worldwide community of scholars through the publication of Anthropological Literature, a quarterly bibliographic author and subject index to over 1,000 serials. Tozzer Library is a unit of the Harvard College Library and has a staff of 15 , including 6 professionals.

Major Benefits: One month's vacation, generous holiday and sick leave, choice of health plans, life insurance, University-funded pension plan, tuition assistance.

Please submit resumes and three sources for current references to:

\author{
Susan Lee \\ Personnel Librarian \\ Harvard College Library \\ Widener Library, Room 98 \\ Cambridge, MA 02138 \\ (617) 495-3721
}

An affirmative action, equal opportunity employer 
aloging activities; familiarity with national cataloging standards including LC classification and subject headings, OCLC (preferably), national issues facing academic research libraries in bibliographic access and automation. Required are an ability to communicate well orally and in writing; good supervisory and problem- solving skills; commitment to high productivity and high quality cataloging in all formats. Some foreign language background in a Western European language is preferred; familiarity with the scholarly research process and the complexities of a large research library's online public catalog preferred. Minimum Salary: $\$ 30,000+$ for 12 months commensurate with experience. Benefits include 30 vacation days per year, vested retirement after 5 years, dental insurance, and other normal fringe benefits, including $75 \%$ tuition waiver. Columbia is in the middle of the state on 1.70, only 2 hours from St. Louis and Kansas City, and 1.5 hours from the Lake of the Ozarks major recreational area. The University and two other colleges provide superb cultural events. According to the ACCRA Composite index, the cost of living in Columbia is very reasonable when compared with other university communities. Available: January 1, 1990. Send letter of application, names of three references, and resume to: Pat Burbridge, Personnel Coordinator, 104 (CLN) Ellis Library, University of MissouriColumbia, Columbia, MO 65201-5149. Applications received by September 30, 1989, will receive first consideration. The University of Missouri-Columbia is an equal opportunity, affirmative action employer and employs only U.S. citizens and lawfully authorized alien workers.

HEAD, CATALOG AND DATABASE MAINTENANCE SECTION. Responsible to the Head of the Cataloging Department for the supervision of seven support staff in the maintenance of the NOTIS online bibliographic database, shelf list, online authority files. Responsible for the accuracy of headings added to the online catalog, for advising on name and subject authority questions, and for communication with other Library units on matters relating to bibliographic records. Participates in Department planning and may do original cataloging.
Qualifications: Master of Library Science from ALA-accredited school; a knowledge of LC classification schedules and subject headings, AACR2, MARC formats, and OCLC; at least one year's relevant experience in an academic library cataloging department, a working knowledge of at least one foreign language and some supervisory experience. Familiarity with authority work and experience with online catalog desirable. Should have good communication skills. Salary: Dependent on qualifications with a $\$ 25,000$ minimum. Start date: as soon as possible. Send resume and references to: Peggy Weissert, Library Personnel Officer, Theodore M. Hesburgh Library, University of Notre Dame, Notre Dame, IN 46556, by August 15, 1989, for ensured consideration. An Affirmative Action, Equal Opportunity Employer.

HEAD, REFERENCE SERVICES. Responsibilities: The University at Albany, State University of New York, seeks a dynamis, innovative leader and effective manager to direct the Libraries' programs and collections in reference and government publications, online and CD-ROM searching, and bibliographic instruction. Supervises 9.5 FTE librarians, 6 FTE support staff and student assistants. Plans, develops, and evaluates collections, programs, and policies. Participates actively in library administration and faculty governance. Fulfills academic faculty responsibilities for promotion and tenure. Qualifications: MLS from an ALA-accredited institution. Substantial reference experience including supervisory responsibilities; experience with library computer technology; experience with collection development; ability to establish effective working relationships with faculty, staff and students in a culturally diverse environment; knowledge of trends and issues in academic libraries; the ability to participate in systematic planning; strong commitment to service; evidence of research, publication, and/or professional activity. Salary: commensurate with education and experience, mid-\$20s-high-\$30s. Apply to: Christine M. Travis, Library Personnel Officer, University Libraries-UL 139, The University at Albany, State University of New York, 1400 Washington Avenue, Albany, NY 12222. Deadline:

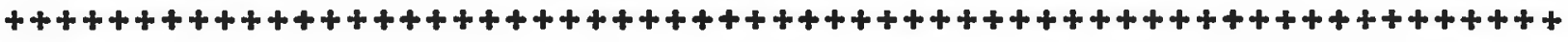

\section{SLAVIC CATALOGER}

\section{The University of California, Berkeley}

Assistant or Associate Librarian. The Library's Catalog Department at Berkeley is responsible for original cataloging in all languages except Chinese, Japanese, and Korean for the Main Library and its 23 branches.

Currently the Department seeks a Slavic Cataloger to perform original cataloging of monographic and microform materials in sciences, technology, humanities, and social sciences in all Slavic languagespredominantly Russian. The Cataloger is responsible for full MARC coding of cataloging records input to the UC Berkeley online catalog. Other duties include contributing to the development of the online public access catalog, training staff, and assisting copy catalogers. University of California Librarians are expected to contribute to the profession outside the primary assignment through such activities as Library or University service, participation in professional associations, or publication.

An MLS from an ALA-accredited library school or equivalent is required, as is thorough familiarity with the Anglo-American Cataloging Rules, 2nd edition, the Library of Congress Rule Interpretations, Library of Congress Subject Headings and Classification Schedules, and the MARC format. Fluency in Russian is essential. Knowledge of one of the Western Slavic languages, preferably Polish, is highly desirable, along with recent original cataloging experience and knowledge of automated databases such as OCLC and/or RLIN. A strong background in sciences and humanities, of the latter preferably in Slavic studies, is required; an advanced degree in such a field is highly desirable.

Rank and salary ( $\$ 26,136-\$ 33,444 /$ year) based on qualifications. Position available September 1, 1989. Closing date for applications: July 16, 1989. Apply in writing, including with your letter a statement of qualifications, resume of education and experience, and the names and addresses of 3 references.

Apply to:

\section{Janice Burrows \\ Director of Library Human Resources \\ 447 Library, University of California \\ Berkeley, CA 94720}

The University of California is an equal opportunity, affirmative action employer 
Review of letters of application and resumes will begin July 31, 1989 Please include a list of three persons with addresses whom we can contact for references. The University at Albany, State University of New York, is an equal opportunity, affirmative action employer. Applications from women, minority persons, handicapped persons, special disabled and Vietnam veterans are especially welcome

LIBRARY/LEARNING CENTER DIRECTOR, University of Wisconsin-Parkside. The University of Wisconsin-Parkside, one of 13 degree-granting campuses in the distinguished University of Wisconsin System, seeks a Library/Learning Center Director. The Library/Learning Center has a commitment to facilitating faculty and student research, a strong service orientation, and a nationallyknown program of bibliographic instruction. In addition to the traditional areas of Technical Services and Public Services, the library includes the Archives and Area Research Center and the Media Services Division, which is responsible for the promotion of instructional materials as well as the maintenance and scheduling of equipment. The library now operates an LS/2000 automated library system and is in the process of implementing acquisitions and serials control modules. The Library/Learning Center has 11 professionals, 12 support staff, and 65 student employees. The collection includes 347,000 volumes, 770,000 units of microform, and 17,000 audiovisual titles. The $1988-89$ budget is approximately $\$ 1,150,000$. In this time of unprecedented change in academic libraries, the position of Director offers exciting challenges and opportunities calling for leadership, initiative, and foresight. Candidates for the position should have an MLS degree from an ALA-accredited library school. Also required is expertise in key administrative activities such as planning, budgeting, and personnel management; enthusiasm for and commitment to flexibility and creativity in adjusting library resources to (UW-Parkside's distinctive mission, which entails meeting the needs of both a non-traditional student body and a researchoriented faculty; a thorough knowledge of current developments in library technology and systems; and the ability to work effectively with all segments of the university and with other libraries in the UW system and the region. Significant activity with professional library associations and a publication record are desirable. The Director reports directly to the Vice Chancellor. Salary range is $\$ 45,000-\$ 55,000$. Qualified candidates should send a letter of application, a complete resume, and the names, addresses, and telephone numbers of four references to: Donald D. Kummings, Chair, Library/Learning Center Search and Screen Committee, University of Wisconsin-Parkside, Kenosha, WI 53141-2000, by September 1,1989 . Late submissions will be considered if a suitable candidate pool is not identified by the deadline. Effective starting date is January 1990, or as soon as possible thereafter. UW-Parkside is an Equal Opportunity, Affirmative Action institution.

\title{
THREE REFERENCE LIBRARIAN POSITIONS
}

\section{The University of Alabama Libraries}

\author{
Title: Reference Librarian (Instructor), Business Reference Librarian (Assistant Professor), Science \\ and Engineering Reference Librarian (Assistant Professor).
}

Responsibilities: To provide, under the supervision of the Head of the Reference Department, the Head of the Business Library, and the Head of the Science and Engineering Library, a full range of services, including development and interpretation of the appropriate reference sources to the university community, subject assigned collection development including faculty liaison, library user instruction, database and end-user searching and instruction, supervision of classified personnel and student assistants, and other duties as assigned. Some evening and weekend reference service required

Qualifications: Required: An MLS from a program accredited by ALA; in-depth knowledge of basic general and subject reference sources, national and trade bibliographies; ability to work effectively with faculty, students, and library personnel at all levels; excellent oral and written communication skills; commitment to client-centered services. Desired: Working knowledge of a foreign language; subject reference experience in a large academic or special library; experience in online searching, government documents, and bibliographic instruction; evidence of professional and/or scholarly activity. Second master's degree in relevant subject highly desirable.

Salary and Benefits: Twelve-month, faculty-rank, tenure-earning, strong benefits. Appointment of Reference Librarian will be at the Instructor level with a beginning salary of $\$ 19,500$. Appointment of the Business Reference Librarian will be at the Assistant Professor level with a minimum salary of $\$ 23,500$. Appointment of the Science and Engineering Reference Librarian will be at the Assistant Professor level with a minimum salary of $\$ 23,500$.

Projected Starting Date: October 1, 1989 (negotiable).

To Apply: Applicants are invited to apply for one or more positions depending on credentials and interests.

Send letter of application, resume, and names and addresses of three references to:

\section{Sondra Tucker \\ Libraries Personnel Officer \\ The University of Alabama \\ Reference Librarian Searches \\ P.O. Box 870266 \\ Tuscaloosa, AL 35487-0266}

The application deadline is August 20, 1989.

The University of Alabama is an equal opportunity, affirmative action employer 
MONOGRAPHS ORDER LIBRARIAN. Responsibilities: Manages operations of Monographs Order Department, 8 full-time and several part-time employees who do pre-order searching, order generation, receipt, and accounting for approximately 30,000 volumes per year. Works with selectors representing different subject areas in identifying, ordering, and processing new materials for the collection and with Serials and Cataloging in coordinating flow of materials and planning for adequate bibliographic access. Reports to Head of Acquisitions. Required: MLS from an ALA-accredited library school. Preferred: Acquisitions or book trade experience; supervisory experience; familiarity with automated library systems. Salary $\$ 19,000$ plus, commensurate with experience. Salt Lake City is situated in a dramatic mountain setting and offers an excellent quality of life. Hiking, camping, and river-running are available in both mountain and desert red-rock country in summer. Outstanding alpine and nordic skiing in winter. Cultural opportunities include symphony, ballet modern dance, chamber music, opera, theater, and arts film. Applications received by August 31, 1989, will be given first consideration; applications will be accepted until the position is filled. Send letter of application, resume, and names of three references and/or Placement Bureau address to: Dennis R. Defa, 328 Marriott Library, University of Utah, Salt Lake City, UT 84112. The University of Utah is an Equal Opportunity, Affirmative Action Employer. Women and minorities are encouraged to apply.

PHYSICAL SCIENCES REFERENCE LIBRARIAN/BIBLIOGRAPHER. Responsible for the Library's collection development in assigned physical science disciplines. Provides service at information desk, including some weekend and evening hours. Participates in an active program of library instruction and computerized database searching in the disciplines of selection responsibility. Requires

\section{TECHNICAL SERVICES LIBRARIAN \\ Columbia University}

The Library of Barnard College, Columbia University, seeks a Technical Services Librarian to assume responsibility for the integrity of its manual and online bibliographic records. Responsibilities include maintaining the card catalog and shelf list, updating manual records and online data maintenance and assisting in the planning and implementation of NOTIS. In addition, reference duties and collection development responsibilities will be as. signed.

Candidate should have MLS degree, familiarity with automated bibliographic data systems, online operations, AACR2, LC classification, and MARC formats. Related experience preferred.

35-hour week; Sunday-Thursday schedule during the academic year, Monday-Friday when classes are not in session. Starting salary: $\$ 24,000 / y e a r$ and excellent benefits.

Send letters of application with resume and three references to:

\section{Eileen Agard Glickstein \\ Director, Barnard College Library \\ Columbia University \\ 3009 Broadway \\ New York, NY 10027-6598}

Initial review of applications will begin August 21,1989 .

\section{An equal opportunity employer.}

an ALA-accredited Master's degree and significant coursework in physical sciences or significant science reference experience. Ex cellent communication skills and strong service orientation essential. $\$ 20,500$ minimum salary depending on qualifications. Excellent benefits package including choice of retirement programs. The University of Houston Libraries holdings exceed 1.6 million volumes, with a materials budget of $\$ 2.6$ million, and a total staff of 175 . The Library is a member of ARL. To ensure consideration, applications must be received by August 31, 1989. Send letter of application names of 3 references, and resume to: Dana Rooks, Assistant Director for Administration, University of Houston Libraries, Houston, TX 77204-2091. Equal Opportunity Employer.

PRINCIPAL CATALOGER. Associate Librarian or Librarian $(\$ 31,944-\$ 59,556)$ based on qualifications and experience. Open immediately. Responsible for ensuring that original cataloging conforms to national standards and is expected to motivate catalogers to maintain high levels of productivity. Is expected to be innovative and to use creativity in planning and implementing efficient procedures in a manual and automated environment. Responsible for the supervision, training and evaluation of protessional catalogers ( 7 FTE) in the Original Cataloging Section of the Catalog Department which catalogs monographs only. The appointee works closely with the supervisors of the Copycataloging and Postcataloging Sections and with the Department Head in formulating cataloging policies and in managing the Department. Answers questions and resolves problems on request from faculty, staff, and other Library Departments. Serves as Chair of the joint Catalog-Serials Departments' Authority Files Committee. Catalogs material in areas of expertise as time permits. Helps plan for anticipated acquisition of a local integrated online cataloging system. Contributes to Library, University, and professional activities. Qualifications: MLS or equivalent; minimum of five years cataloging experience in a research library, including demonstrated leadership ability and successful supervisory experience. Thorough knowledge of cataloging principles and procedures, including AACR2, LC classification and subject headings, MARC formats, and authority control. Working knowledge of a modern European language (additional language skills desirable). Experience with a major utility, such as RLIN or OCLC. Strong oral and written communication skills. A record of professional achievements is desirable. Experience with a local integrated online cataloging system is highly desirable. Applicants should send letter, resume, and the names, addresses, and telephone numbers of three references (including current supervisor) to: Sandra A. Vella, Assistant Personnel Librarian, 108 Shields Library, University of California, Davis, CA 95616. Telephone: (916) 752-1138. Applications received by July 31, 1989 will be assured consideration. The University of California, Davis is committed to a policy of affirmative action and specifically invites inquiries and applications from women and ethnic minorities.

REFERENCE/INFORMATION RETRIEVAL LIBRARIAN, Memphis State University Libraries. Position will be filled at the Instructor or Assistant Professor level with rank and salary $(\$ 21,000$ minimum) commensurate with education and relevant experience. Position is full-time, tenure-track appointment. Responsibilities involve service at reference desk including evenings and weekend rotation, online database searching (i.e., BRS and Dialog), bibliographic instruction, end-user searching consultation, CD-ROM activities and other duties as assigned. The successful applicant must have superior interpersonal skills as well as excellent written and oral communication skills and the ability to work effectively with patrons and staff. Position requires ALA-accredited master's degree in library or Information science. Preference is given to those applicants who can demonstrate a mix of education, training, relevant academic experience, additional degree work or other characteristics that might contribute to the quality of professional work. Position receives twenty-four (24) days of annual leave, eleven (11) paid holidays, and twelve (12) days of sick leave each year. TIAA/CREF or state retirement options paid by employer. Memphis State University is an Equal Opportunity, Affirmative Action University. The position is available on 1 July 1989 and a review of applicants will begin on that date and continue until the position is filled. Applicants should send a letter of application and resume to: John E. Evans, Head, Reference Department, Memphis State University Libraries, Memphis, Tennessee 38152; (901) 678-2208

REFERENCE LIBRARIAN, Butler University. Full-time, 12-month position available August 16, 1989. Must have ALA-accredited master's degree in library science, three years related experience including online literature searching with DIALOG, BAS, and Wilsontine 
systems, knowledge of CD-ROM databases and strong interpersonal and communication skills. Will provide general reference service, including computerized literature searches, in main university library serving social sciences and humanities disciplines. Some evening work required. Other duties include reference collection development, training and supervision of student assistants, library instruction, and preparation of bibliographies. Salary: $\$ 18,000$. Send resume and letters of reference to: Patricia A. Bacon, Personnel Di rector, Butler University, 4600 Sunset Avenue, Indianapolis, IN 46208. EOE/AA.

REFERENCE LIBRARIAN. Full-time, tenure-track faculty position available September 1989. Responsibilities: Full range of reference and online information services in highly automated library. Qualifications: ALA-accredited MLS required, second master's preferred and required for tenure. Minimum of 2 years relevant reference experience required. Minimum salary: $\$ 25,140$ for Instructor; $\$ 27,900$ for Assistant Professor. Review begins August 1, 1989, and will continue until position is filled. Send letter of application, resume, and the names, addresses, and phone numbers of three references to: Mary Jane Hilburger. Chairperson, Reference Librarian Search and
Screen Committee, Ronald Williams Library, Northeastern Illinols University, 5500 N. St. Louis Ave., Chicago, IL 60625. AA/EOE

REFERENCE LIBRARIAN. Provide general reference service including bibliographic instruction and computer assisted reference. Participate in collection development activities of the department Limited night and weekend duty. Teach in library science curriculum. Qualifications: Required: ALA-accredited MLS. Preferred: Degree in science area or experience with science reference materials. Experience with bibliographic instruction or teaching. Experience with online searching. Second Master's and foreign language(s). Salary and Rank: $\$ 17,500$ minimum for nine months, negotiable depending on qualifications. Additional eight week summer school contract normally available. Faculty appointment at the rank of Assistant Professor in a tenure-track position. Comprehensive insurance including health, dental, and life; State retirement; tuition benefits. SMSU is the second largest public University in Missouri with over 17,000 students and the SMSU Libraries contain over one and one half million iterns. Apply to: Send a letter of application and resume, including the names of three references (with address and telephone number) to: Paul Frisch, Head of Reference, Duane G. Meyer Li-

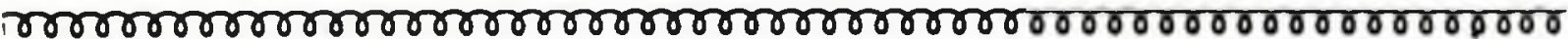

\title{
TWO POSITIONS AVAILABLE
}

\section{Purdue University Libraries}

1) Assistant Management \& Economics Librarian. Requirements: MLS (ALA-accredited). Minimum of 2 years professional reference experience in business or social sciences. Desired qualifications: Reference experience requiring knowledge of traditional as well as computer-based sources; familiarity with literature of business/economics; some knowledge of government documents; ability to develop information literacy skills via in-class bibliographic instruction and end-user training; knowledge of technical services practices regarding acquisition and cataloging of serials; some supervisory experience; an advanced degree in a related field. Responsibilities: Participate in delivery of an active program of reference, orientation, and bibliographic instruction emphasizing acquisition of data-gathering skills at both undergraduate and graduate levels. Responsible for supervision of processing serial publications. Share in management of the library and participate in planning and implementing new programs and services. Salary: $\$ 22,000$ and up depending on qualifications.

2) Physics and Earth \& Atmospheric Sciences Librarian. Requirements: MLS (ALA-accredited). Minimum of 2 years professional experience in an academic or research library. Desired qualifications: Creative and energetic commitment to public services and bibliographic instruction. Ability to work effectively with faculty, students, and staff. Oral and written communication skills. Supervisory skills. Experience with computer-based information services and microcomputer systems. Professional experience with scientific/technical literature. Experience with map collection management. Responsibilities: Directs operations and manages budgets of both the Physics and Earth \& Atmospheric (EAS) Sciences Libraries. Provides reference and general services to faculty, graduate students, and undergraduates in Physics and EAS as well as to the University community. Responsible for collection development. Plans and develops new services. Trains and supervises support staff. Performs liaison work with faculty. Manages the university library's map collection. Makes presentations to university classes and groups on library services, resources, and facilities. Salary: $\$ 24,000$ and up, depending on qualifications.

Status and Benefits: Faculty status and responsibilities, rank commensurate with education and experience. Members of Library faculty must meet Purdue University requirements (excellence in librarianship, research and publishing, and service) for promotion and tenure. 12-month appointment. Annual vacation of 22 working days. Flexible benefit programs. Group life, medical, and disability insurance programs are in effect as are TIAA-CREF and Social Security coverage. Deadline: August 20, 1989, or until position is filled.

Apply to:

\author{
T. L. Haworth \\ Personnel Officer \\ Libraries, Stewart Center \\ Purdue University \\ West Lafayette, IN 47907
}

Send resume and list of references

An EEOIAA Employer 
brary, 901 S. National, Box 175, Southwest Missouri State University, Springfield, MO 65804-0095. Closing Date: Applications re ceived by July 17, 1989, will receive first consideration. Southwest Missouri State University is an equal opportunity, affirmative action employer.

REFERENCE LIBRARIAN: Permanent full-time, tenure-track position. Duties. Reference, online searching, bibliographic instruction, collection development, and serving as a library liaison to a teaching department or departments. Required: Master's degree from an ALA-accredited program; an undergraduate major in education or social sciences. Reference experience in an academic or research library. Strong commitment to public service. Desirable: Two years reference experience and a second master's degree preferred. Coilection development experience and foreign language fiuency desired. Incumbent must comply with the policies of the Faculty Handbook including research, publication, and service to the profession and community. Salary dependent upon qualifications, minimum $\$ 20,000$. Submit resume (including names and addresses of three references) by August 7, 1989, to: Rita Critchfield, General Library Personnel Office, University of New Mexico, Albuquerque, NM 87131. Recruitment will continue until the position is filled. AAVOE.

REFERENCE LIBRARIANS. We are looking for two experienced professionals to work as part of a team in a challenging public service environment. Primary responsibility will be to assist in providing general reference service in the social sciences, humanities, and business. Other shared assignments may include Government Documents, B.I., database searching, disabled student services (one position is new; the other an existing vacancy). Salary:
$\$ 23,000-24,000$. Science Reference Librarian (new position). To assist in providing reference services in the Physical and Biological Sciences, including database searching and B.I. Salary $\$ 24,000-25,000$. All three positions require an MLS degree from an ALA-accredited school, an undergraduate degree in a Science is re quired also for the science position, one year's professional reference experience in an academic library, a working knowledge of a modern European language. Excellent fringe benefits and faculty status. Send resume by July 31st to: James DeLancey, Georgetown University Library, P.O. Box 37445, Washington, DC 20013. Georgetown University is an Affirmative Action, Equal Opportunity Employer.

RETROSPECTIVE CONVERSION AND RECLASSIFICATION CATALOGER (Temporary). Salary from $\$ 20,000$ for 12 months, depending upon qualifications. A temporary faculty-level appointment for 12 months with possible extension. The individual in this position plans and directs the retrospective conversion of non-machinereadable bibliographic records and the recataloging and reclassification of non-LC classified materials to LC classification and cooperates in the development and implementation of collection development policy. Required: an ALA-accredited MLS; knowledge of technical library operations with special emphasis on principles of monographic cataloging using AACR2, LC classification, and LCSH; ability to supervise subordinates and to communicate library policies and procedures to appropriate personnel clearly and tactfully. Desirable: one year directly related experience; knowledge of pre-AACR2 cataloging rules; experience using an online bibliographic utility, such as OCLC; experience using MS-DOS microcomputers; knowledge of one or more Romance languages. Send letter

\title{
UNIVERSITY LIBRARIAN University of Illinois at Chicago
}

The University of Illinois at Chicago, one of two campuses of the University of Illinois, is inviting applications and nominations for the position of University Librarian. UIC is comprised of 15 colleges with 1800 faculty and serving 25,000 students, $30 \%$ of which are graduate and professional students.

Reporting directly to the Vice Chancellor for Academic Affairs, the University Librarian is responsible for the leadership and administration of the University Library, consisting of the Main Library, the multi-site Library of the Health Sciences, the Science Library, the Architecture and Art Library, and the Mathematics Library, with a collection of 1.6 million volumes, 18,000 serials, and 2.6 million other items including microforms, government documents, and maps.

Candidates for the position should have the following qualifications: an earned Master's of Library Science from an ALA-accredited library school; a distinguished record of accomplishment in librarianship, in research, and in service to the profession to warrant appointment as a tenured full professor; demonstrable commitment to the ideals and principles of a Research I university; leadership and commitment in planning for and applying contemporary and emerging technologies; demonstrable commitment to working with the academic community to ensure responsive library service; capacity for establishing beneficial developmental relationships with alumni, community and business leaders, and private and governmental funding agencies; demonstrable academic leadership and library management skills in a complex, multi-site library; evidence of ability to further relationships with campus constituencies, with libraries, and with associations and agencies at the local, state, regional, national, and international levels.

Salary Range: $\$ 70,000$ to $\$ 95,000$.

The Search Committee will begin screening September 1, 1989 and will continue until the position is filled. To ensure full consideration, applications should be received by September 1, 1989.

Applications, accompanied by the names and addresses of five references and a complete curriculum vitae, should be sent to:

\author{
Henri R. Manasse, Jr. \\ Chair, University Librarian Search Committee \\ c/o Office of Academic Affairs \\ 2832 University Hall, m/c 105 \\ University of Illinois at Chicago \\ Box 4348, Chicago, IL 60680
}




\section{ADELPHI UNIVERSITY LIBRARIES FIVE POSITIONS}

Adelphi University, the oldest private institution of higher education on Long Island, serving over 10,000 graduate and undergraduate students, seeks experienced, energetic and resourceful individuals for the following library administrative and faculty appointments. For each position, MLS from ALA accredited library school and significant and relevant experience is required. Currently, Adelphi is undergoing challenging and exciting changes, including a re-definition of its mission and goals and a revision of its curriculum. The University Libraries contain over 580,000 volumes and maintain $4,8,00$ current serials subscriptions. Fully automated systems (OCLC, CLSI, and INNOVACQ) support online catalogs, as well as circulation, acquisitions, and serials functions. Plans for a new integrated system are currently in progress.

\section{Associate Dean of Libraries for Technical and Automated Services (Administrative Appointment)}

As a senior administrator heading a major division of the University Libraries, responsibilities include overall planning, development, management, and coordination of acquisitions, cataloging, and automated systems and assisting the Dean in a variety of library-wide administrative responsibilities. Salary $\$ 40,000$ minimum; 12 month appointment (22 days vacation); available November 1, 1989; screening will begin September 1.

\section{Part-fime Librarian, Adelphi Huntington Center, Huntington, NY (Librory Foculty Appointment- Non-Tenure Track)}

Responsible for the operations and services of the Huntington Center Library and the University's Library Storage Annex. Hours will vary according to needs of the Library but will be primarily afternoons and evenings. Salary $\$ 15,000$ minimum; 20 hours per week, 11 months per year; available September 1, 1989; screening will begin July 15 .
Part-time Temporary Reference Librarian (Fall Semester, 1989) (Library Faculty Appointmenttemporary, Non-Tenure Track)

Provision of reference desk services and other duties as assigned. 12 hours per week; minimum salary $\$ 13$ per hour; available September 1, 1989; screening will begin July 15.

\section{Two Tenure Track Library Faculty Appointments}

1. Coordinator of Nonprint Media Services (Re-opened search): Planning, development, and day-to-day operations of Nonprint Media Services (including general nonprint software and hardware collections, curriculum materials, services to the handicapped, equipment delivery services, a small computer laboratory) and shared administrative responsibility for the language laboratory.

2. Systems Librarian/Cataloger: Planning, implementation, operation, and maintenance of the Libraries' automated systems and some cataloging responsibilities (preferably serials).

For both tenure track positions: Salary $\$ 26,000$ minimum for a 9.5 month work year, with possible option for a longer work year at pro-rated compensation. Second advanced degree is highly desirable and will be required for tenure. Available February 1, 1990; screening will begin September 1. Applications for interim appointments to both positions are being considered immediately. Interim appointees will serve as visiting instructors or professors, starting as soon as possible and continuing at least through January, 1990.

Excellent benefits package (including TIAAVCREF or alternative retirement plans) provided for full-time positions but not for part-time positions.

Submit letter of application (specifying which position and whether interim or permanent), curriculum vitae, and names and addresses of three references to: Eugene T. Neely, Dean of Libraries, ADELPHI UNIVERSITY, Garden City, NY 11530

Adelphi is an Equal Opportunity Alfirmative Action Employer M/F

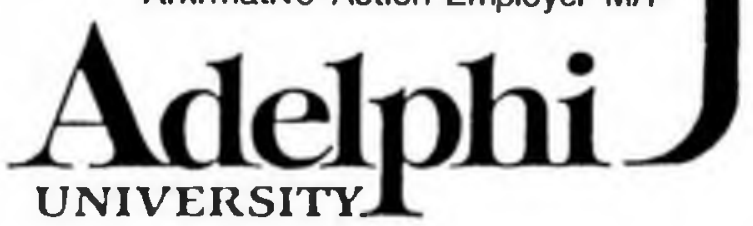


of inquiry or call for complete job description and application process to: Trisha Long, Administrative Secretary, James B. Duke L brary, Furman University, Greenville, SC 29613; (803) 294-2191 Applications must be complete by August 4, 1989 .

SERIALS CATALOGING SECTION HEAD, University of California, Santa Barbara (Search Extended). Supervises serials section of Cataloging Department. Duties include original cataloging and classification of serials and analytics, revision of contributed cataloging work by library assistants, and resolution of complex bibliographical problems. Requirements: MLS, at least two years recent professional experience in serials cataloging, experience with AACR1 and AACR2, LC classification and LC subject headings, online cataloging systems, and supervisory experience. Facility with European languages and automated serials cataloging desired. Salary range: $\$ 26,136-\$ 46,020$ dependent upon experience and qualifications. Applications must be received by August 31, 1989. Send letter of application, names of 3 references, and resume to: Margaret Deacon, Associate University Librarian, UCSB Library. University of California, Santa Barbara, CA 93106. UCSB is an equal opportunity, affirmative action employer. Proof of U.S. citizenship or eligibility for U.S. employment required prior to employment.

SERIALS ORDER LIBRARIAN. Responsibilities: Manages Serials Order, seven full-time and three part-time employees who are responsible for pre-order searching, downloading OCLC records or creating temporary bibliographic records, creating purchase orders, serial check-in, and serial accounting. Works with selectors representing different subject areas throughout the library in identifying, ordering, and processing new materials for the library, with Monographs Order and Cataloging in coordinating the flow of materials and planning for adequate bibliographic access, and with faculty and patrons who have questions about the serials collection. Reports to Head of Acquisitions. Required: MLS from an ALAaccredited library school. Preferred: Serials experience; supervisory experience; familiarity with automated library systems. Salary: Minimum $\$ 19,000$ plus, commensurate with experience. Salt Lake City is situated in a dramatic mountain setting and offers an excellent quality of life. Hiking, camping, and river-running are available in both mountain and desert red-rock country in summer. Outstanding alpine and nordic skiing in winter. Cultural opportunities include symphony, ballet, modern dance, chamber music, opera, theater, and arts film. Applications received by August 31, 1989, will be given first consideration; applications will be accepted until the position is filled. Send letter of application, resume, and names of three references and/or Placement Bureau address to: Dennis R. Defa, 328 Marriott Library, University of Utah, Salt Lake City, UT 84112. The University of Utah is an Equal Opportunity, Affirmative Action Employer. Women and minorities are encouraged to apply.

SLAVIC/SOCIAL SCIENCES CATALOG LIBRARIAN (Position Reopened). The University of Arizona is seeking a librarian to provide original and complex copy cataloging for Slavic language materials and monographs in the social sciences. The person in this position would serve as a cataloging resource person for library staff in the above languages and subject areas. Librarians at the University of Arizona have academic professional status, are eligible for continuing status, are voting members of the faculty and may take up to 24 days professional leave per year. They have 22 days paid vacation, 12 days sick leave, and 10 holidays per year. A standard package of fringe benefits is available. Requirements include a Master's degree in Library Science from an ALA-accredited school; fluency in Russian; knowledge of or experience with AACR2, MARC formats, LCSH and LC romanization tables, OCLC or other bibliographic utility; and good oral and written communication skills. Candidates with knowledge of other Slavic languages and background in the social sciences will be given preference. Preference will be given to women and minorities. Salary based on qualifications and experience; beginning professional salary is $\$ 20,000$. Applications must be received by August 15, 1989. Send letter of application, resume, and the names of three references to: $W$. David Laird, University Librarian, University of Arizona Library, Tucson, AZ 85721. The University of Arizona is an equal employment opportunity employer with an affirmative action plan. Non-citizens must include current visa status.

SYSTEMS COORDINATOR, with faculty rank; available Summer 1989. To coordinate library's automated system (NOTIS), supervise database maintenance activities (cataloging, authority control), and coordinate use of IBM microcomputer classroom. MLS from an ALAaccredited program or MS in information science required. Minimum salary $\$ 22,000$. Salary commensurate with experience. Send application, resume, transcripts, and three letters of recommendation to: David W. Jordan, Vice President for Academic Affairs, Austin College, Sherman, TX 75091-1177. Review of candidates will hegin July 10,1989 EOE

\section{LATE JOB LISTINGS}

\section{ASSISTANT UNIVERSITY LIBRARIAN FOR COLLECTION}

MANAGEMENT, Northwestern University Library. The Assistant University Librarian for Collection Development is responsible for all aspects of collection management at Northwestern University Library (excludes the Health Sciences and law libraries). These responsibilities include setting and interpreting selection policy, allocating acquisition funds, overseeing the preservation program, planning and budget preparation,and ensuring effective communication with the faculty. Has a major involvement in fundraising activities. Also has a principal role in the general administration of the Library. Represents the Library in regional and national planning for collection management. Qualifications: Master's degree from an accredited library school required: advanced degrees in a subject field strongly desired. Five years experience in various aspects of collection management required, preferably in positions of increasing administrative responsibility. Demonstrated organizational, supervisory, planning, and communication skills required. Fundraising experience highly desired. Leadership skills and a strong vision of library services essential. Salary: $\$ 50,000$ minimum. Send letter of application and resume to: Northwestern University Library, Ann Smith, Personnel Manager, 1935 Sheridan Road, Evanston, IL 60208. Applications received by September 20, 1989, will receive first consideration. EEO/AA Employer. Employment eligibility verification required upon hire.

\section{AUTHORITIES LIBRARIAN/MONOGRAPHIC CATALOGER. Oversees} authority control operations for the Northwestern union online catalog, 
including training and supervision of authorities assistants, and training and liaison with union catalog participants. Assists in development of authority control mechanisms and policies for the University Library and the NOTIS system. Performs original and complex copy cataloging and classification of monographs in a variety of subjects and languages. Cataloging is performed on NOTIS for inclusion in OCLC using AACR2, rev., DDC20, and LCSH. Qualifications: ALA-accredited MLS. Three years cataloging experience, including authority work, preferably in a research library using an automated system. Familiarity with the MARC bibliographic and authorities formats. Working knowledge of two or more modern European languages preferably including German and a Romance language. Demonstrated supervisory skills preferred. Starting salary: $\$ 23,000-\$ 27,000$. Send letter of application and resume, including names of three references, by September 1, 1989 to: Ann Smith, Personnel Manager, Northwestern University Library, 1935 Sheridan Road, Evanston, IL 60208. EEO/AA Employer. Employment eligibility verification required upon hire.

\section{BIBLIOGRAPHIC INSTRUCTION/REFERENCE LIBRARIAN, Joyner}

Library, East Carolina University. Responsibilities: Responsible for development, implementation, and evaluation of the library bibliographic instruction program, including use of the online catalog and CD-ROM databases. Participates in all aspects of reference service, acts as liaison to assigned academic departments, and develops the reference and stack collections in these areas. Qualifications: ALA-accredited MLS, strong oral and written communication skills, reading knowledge of a foreign language. Preferred: minimum of two years experience in bibliographic instruction in an academic or research library, second master's degree, experience with library applications for microcomputers. Twelve-month, tenure-track faculty appointment. Salary $\$ 22,000$ minimum, depending on qualifications. Research and publication expected for tenure and promotion. Reference department staff of twelve includes nine librarians. East Carolina University's libraries serve a campus community of over 15,000 students and 950 faculty. The University is a constituent institution of the sixteen-campus University of North Carolina. Screening of applications will begin August 1, 1989 and continue until position is filled. Send letter of application, resume, copies of transcripts, and names of three current references to: Dr. Jo Ann Bell, Acting Director of Academic Library Services, Joyner Library, East Carolina University, Greenville, NC 27858-4353. Official transcripts from each college or university attended will be required prior to any offer of employment. Federal law requires proper documentation of identity and employability at the time of employment. It is requested this documentation be included with your application. East Carolina University is an affirmative-action, equal opportunity employer and, as such, encourages applications from women, blacks, and other minorities.

BUSINESS REFERENCE LIBRARIAN/BIBLIOGRAPHER. The Business Reference Librarian/Bibliographer is responsible for collection development in business, with special emphasis in Accounting, Management, and Marketing. Serves as faculty liaison to departments within the School of Business Administration. Provides reference/users services, including online searching (with assistance from our Computer Services Librarian), bibliographic instruction, and other duties as assigned. Reports to Head, Humanities and Social Science Department. Qualifications: An MLS from an ALA-accredited program; business reference experience, experience with online searching and microcomputers. Strong interpersonal skills and service commitment; effective oral and written communication skills; commitment and ability to work collegially. Advanced subject degree in a Business field preferred. The Miami University Libraries contain over 1.4 million volumes, have an extensive collection of government documents and microforms, and subscribe to over 
12,000 serials. They serve 800 teaching and research faculty, 15,000 undergraduates, and 1,000 graduate students. The library has 34 professional librarians and 55 support staff. Miami University is a highly selective institution, located in Oxford, Ohio, 35 miles northwest of Cincinnati. Benefits include Blue Cross/Blue Shield, major medical, disability, dental, and term life insurances all paid by the University. Public employees retirement system. Salary level begins at $\$ 23,000$. Submit letter of application, resume, and names, telephone numbers, and addresses of three professional references to: Judith A. Sessions, Dean and University Librarian, Miami University, Oxford, $\mathrm{OH}$ 45056. Preliminary screening of applications will begin August 1, 1989. Miami University is an equal opportunity employer.

CATALOGER FOR CLASSICS AND LITERATURE, Original Monographs Cataloging Department. Primary responsibility for providing original and selected member copy cataloging according to AACR2, LC rule interpretations, and local cataloging and authorities policy and procedures, and supplying LC subject headings and LC classification for monographs in literature, linguistics, and the classics published in Western European languages (excluding Spanish, Portuguese, Italian), Latin, and Greek for all CU libraries (except Rare Book), Western European language monographs in all subjects for East Asian and Journalism libraries, monographs for the Papyrus/Epigraphy Collection (primarily classics titles), and some non-book formats cataloging for all CU libraries. Responsibilities also include back-up and assistance to other original catalogers; performing auxiliary cataloging duties including MARC tagging revision, catalog editing, filing, etc.; contributing to departmental and divisional policy and procedure development (identifying issues, providing feedback, completing writing assignments, and committee/task force participation); and providing departmental support. The Original Monographs Cataloging Department is part of the Libraries' Bibliographic Control Division (other units are Cataloging with Copy, Serials Cataloging and Catalog Maintenance). The division provides cataloging via RLIN for about 100,000 titles per year. Cataloging records are made accessible and maintained via CLIO, our NOTISbased online public access catalog. In addition to an accredited MLS, requirements are: working knowledge and relevant experience with cataloging principles and procedures including AACR2, LC subject headings and classification, MARC tagging, and a national online cataloging system (RLIN or OCLC); strong reading knowledge of Latin, French, and German; in-depth knowledge of classical literature, world literature, and the humanities; evidence of initiative and superior organizational skills; and excellent communication, interpersonal, and writing skills. Reading knowledge of Greek is preferred. Salary ranges are: Librarian I: $\$ 26,000-\$ 33,800$; Librarian II: $\$ 28,000-\$ 37,800$; Librarian III: $\$ 31,000-\$ 44,950$. Excellent benefits include tuition exemption for self and family and assistance with University housing. Send resume listing names, addresses, and phone numbers of three references, to: Kathleen M. Wiltshire, Director of Personnel, Box 35 Butler Library, Columbia University, 535 West 114th Street, New York, NY 10027. Deadline for applications is August 31,1989. An affirmative action, equal opportunity employer.

CATALOGING SUPERVISOR, Cataloging with Copy Department. The Columbia Libraries are in the process of implementing an online integrated system for information services. A central component of the system is the online catalog, CLIO, which became a NOTIS-based system in Spring 1989. The Libraries add approximately 100,000 new catalog records each year, and will be engaged for some time in continuing retrospective conversion of older records. We seek a Cataloging Supervisor with the skills, vision and energy needed to assist in the transition to a locally based catalog while maintaining high cataloging production standards. Reporting to the Head of Cataloging with 
Copy, the Cataloging Supervisor supervises departmental staff working with LC and other approved copy, participates in reviewing and altering methods of workflow and cataloging policies within the department, and participates in planning related to the Libraries' bibliographic control functions. In addition, the incumbent performs original cataloging of rush material in all western languages and in one specially assigned subject or language area. With the transition to a NOTIS-based catalog, it is anticipated that the incumbent will plan new workflows for record maintenance including the processing of added locations, added copies, and new routines for bibliographic maintenance. The Cataloging with Copy Department (3 librarians, one supervisor, 23 support staff, and 3 FTE student assistants) has responsibility for copy cataloging and the input of bibliographic records into RLIN and the Libraries NOTIS-based catalog. The Department is one of four departments within the Bibliographic Control Division, which includes Original Monographs Cataloging, Catalog Maintenance, and Serials Cataloging. In addition to an accredited MLS, requirements are: strong organizational and analytical skills; effective verbal and written communications skills; knowledge of cataloging principles, MARC formats, LC subject headings and classification; and working knowledge of one or more Western European languages. Experience in technical services, knowledge of automated cataloging procedures, research library and supervisory experience, and experience in the use of RLIN and NOTIS are desirable. Salary ranges are: Librarian I: $\$ 26,000-\$ 33,800$; Librarian II: $\$ 28,000-\$ 37,800$; Librarian III: $\$ 31,000-\$ 44,950$. Excellent benefits include tuition exemption for self and family and assistance with University housing. Send resume listing names, addresses, and phone numbers of three references, to: Kathleen M. Wiltshire, Director of Personnel, Box 35 Butler Library, Columbia University, 535 West 114th Street, New York, NY 10027. Deadline for applications is August 31, 1989. An affirmative action, equal opportunity employer.

CIRCULATION LIBRARIAN. Administers central circulation and bookstacks. Responsibilities include management of a large and complex central operation of a decentralized library system; policy making, goal setting, planning and evaluation; assurance of efficient circulation services to the University community as well as its broader constituency who has access to the collection by way of ILLINET Online, the statewide online union catalog and circulation system; participation in the development and enhancement of the circulation function as an integral part of the Library's online information retrieval system; management, maintenance, and attention to the preservation of the 5 million volume bookstacks collection; supervision of a large and varied staff; space utilization planning; provision of instructional and other specialized services; oversight of an in-house binding operation; and maintenance of effective working relationships with other departments including more than 35 circulating units and subject collections located both in the main library and elsewhere on campus. Department: The Circulation Librarian is a member of the Library Administrative Council and reports to the Director of General Public Services who reports to the University Librarian. The Circulation Librarian is assisted by the Circulation Manager, 24 FTE support staff, 2 FTE graduate assistants, and 30,000 hours of annual student help. Central Circulation, open 102 hours per week, circulates approximately .5 million volumes annually. The Bookstacks collection houses two-thirds of the Library's holdings, an expensive microform collection, and a separate current periodical section. Half the collection is located in a new stack addition furnished with compact mobile shelving. The circulation function is part of ILLINET Online, which employs the Library Computer System (LCS) linked to the Western Library Network online catalog software. Qualifications: Required: MLS/ALAaccredited. Four years of increasingly more responsible professional library experience including administration and staff supervision, preferably in a large 
research library. Highly developed management, interpersonal communications, and leadership skills. Strong commitment to responsive and innovative public service. Understanding of the dynamics of large organizations and ability to work effectively in a changing environment. Ability to meet University standards of research, publication, and service. Preferred: Prior experience with circulation services in a large library unit and with an automated circulation system. Salary/Rank: $\$ 40,000$ upward, depending on experience and accomplishments. Twelve-month appointment. Faculty rank-level dependent on qualifications. Must engage in research, publication, and university/professional/community service in order to meet University standards for tenure and promotion. Application: Send application, resume, names, and addresses of five professional references by September 15, 1989, to: Allen G. Dries, Library Personnel Manager, University of Illinois Library (UC), 1408 W. Gregory Drive, Urbana, IL 61801. Phone (217) 333-5494. Further Inquiry: Contact David Cobb, Chairperson, Search Committee, (217) 333-0827. The University of Illinois is an affirmative action, equal opportunity employer.

DIRECTOR OF SPECIAL COLLECTIONS. The University of New Mexico General Library offers an exciting opportunity for someone of vision, energy, and enthusiasm. The right person will use experience and imagination to lead a dynamic and innovative special collections department in a period of transition and growth. We are searching for an "entrepreneur" who will provide the leadership required to direct the Special Collections Department, the pivotal department of the General Library's newly-established Center for Southwest Research. We need someone with knowledge of the Southwest and strong communication skills; a record of, or strong potential for, creative fundraising for new and established programs; experience with and commitment to automation; the willingness and demonstrated ability to manage a department within a collegial environment; the ability to create and develop programs; and experience with or knowledge of higher education in an academic setting. This individual will manage an established Special Collections department; inspire, motivate, and direct staff; raise funds; be instrumental in the development and growth of the Center for Southwest Research; play an important role in the team management of the General Library; create matter from energy; take risks; and garner good will and support from public and private sectors. This position requires an MLS from an ALA-accredited program and/or Ph.D. or other doctoral degree. The Special Collections Department is a major resource center for the study of the American West, especially the Southwest. The department has active reference, collection development, automation, preservation, outreach, and oral history programs. It houses manuscripts, architectural collections, photoarchives, rare books, congressional papers, university records, and specialized Hispanic, Native American, and Latin American materials. Services are provided by three faculty and eight staff. The Center for Southwest Research fosters university-wide interdisciplinary study of research pertaining to the Southwest. The programs and services of the Center are open for innovation, research, and development. The Center currently incorporates the Special Collections Department and affiliated research projects and academic programs in a federated arrangement directed by the Dean of Library Services. The General Library, with a collection of over $1,300,000$ volumes, is a member of the Association of Research Libraries and the AMIGOS Bibliographic Utility. The collection is located in Zimmerman Library and four branches. The General Library utilizes the LS/2 circulation system, INNOVACQ acquisitions and serials control system, and Carlyle online catalog. The Library is administered and managed by the Dean, Associate Dean, and the Library Management Team which also includes the directors of the branch libraries and centers and heads of departments. The Management Team makes broad operational, personnel, and budgetary decisions while leaving considerable latitude to department heads in managing their 
departments. The University of New Mexico main campus has an enrollment of 24,500 and employs 1,400 faculty and 3,800 staff. The institution serves a multi-cultural state and the student body is one of the most ethnically diverse in the nation. UNM offers 54 master's degrees and 35 doctoral and professional degrees. Salary is negotiable from $\$ 35,000$. This is a twelve-month, tenure-track faculty position. Rank is negotiable from Assistant Professor. It is assumed that the incumbent in the position will comply with the policies of the Faculty Handbook including research, publication, and service to the profession and community. Submit a resume (including names, addresses, and phone numbers for at least three references) and a letter of application to: Rita Critchfield, Personnel Office, General Library, University of New Mexico, Albuquerque, NM 87131. Applications received by September 1, 1989, will be given first consideration. Position is contingent on available funds. Recruitment will continue until position is filled. UNM is an equal opportunity, affirmative action employer.

GIFT BOOKS LIBRARIAN. Responsible for enhancing a book donor program, acknowledgment, evaluation, and placement of donated materials; managing duplicate book exchange program; selection of memorial requests. Shares professional coverage in Reference and Public Services, including weekend and evening rotation. Requirements include ALA-accredited MLS and demonstrated ability to use OCLC and DIALOG. Minimum Salary: $\$ 19,000$. Excellent benefit package. This is a 12 -month, faculty-rank position. Available July 1,1989 . Send letter of application and resume to: Director of Personnel, Gannon University, University Square, Erie, PA 16541, by August 1, 1989. Gannon University is a selectively comprehensive Catholic teaching University with 4,500 students engaged in 55 undergraduate and 10 graduate programs, and is an Equal Opportunity, Affirmative Action Employer.

GOVERNMENT DOCUMENTS LIBRARIAN, Joyner Library, East Carolina University. Responsibilities: Participates in all documents services, collection development, reference service, bibliographic instruction, CD-ROM, and online datafile searching. The collection includes federal depository, North Carolina state, United Nations, and selected foreign and international government publications. Position reports to Head, Government Documents Department/North Carolina Collection. Qualifications: ALA-accredited MLS; knowledge of reference and bibliographic sources; effective oral and written communication skills; experience in use of online databases. Twelve-month, tenure-track faculty appointment. Salary $\$ 22,000$ minimum, depending on qualifications. Research and publication expected for tenure and promotion, Government Documents and N.C. Collection Department staff of seven includes four librarians. East Carolina University's libraries serve a campus community of over 15,000 students and 950 faculty. The University is a constituent institution of the sixteen-campus University of North Carolina. Screening of applications will begin August 1, 1989 and continue until position is filled. Send letter of application, resume, copies of transcripts, and names of three current references to: Dr. Jo Ann Bell, Acting Director of Academic Library Services, Joyner Library, East Carolina University, Greenville, NC 27858-4353. Official transcripts from each college or university attended will be required prior to any offer of employment. Federal law requires proper documentation of identity and employability at the time of employment. It is requested this documentation be included with your application. East Carolina University is an affirmative-action, equal opportunity employer and, as such, encourages applications from women, blacks, and other minorities.

GOVERNMENT PUBLICATIONS LIBRARIANS (two positions), San Diego State University Library. Responsibilities: 1) U.S. Specialist: Serve at Government Publications Reference desk, including rotating evening and 
weekend duty. May include occasional service at General Reference desk. Participate in full range of public services activities including computer searching, library instruction, and preparation of library guides. Select materials in assigned subject area(s) in addition to U.S. publications. Assist with coordinating and maintaining government information in electronic formats. Participate in local cataloging of U.S. publications and in planning for their inclusion in an INNOPAC online catalog. May be assigned to develop a local documents collection. Participate in committee work and perform other duties as assigned. 2) U.N. Specialist: Serve at Government Publications Reference desk, including rotating evening and weekend duty. May include occasional service at General Reference desk. Participate in full range of public services activities including computer searching, library instruction, and preparation of library guides. Select materials in assigned subject area(s) in addition to U.N. publications. Responsible for maintenance of U.N. collection, including cataloging and supervision of processing. Participate in planning for inclusion of U.N. publications in INNOPAC online catalog. Participate in committee work and perform other duties as assigned. Qualifications: MLS or equivalent from ALA-accredited school required. Demonstrated commitment to public service with excellent interpersonal and communication skills. Desirable qualifications: experience with government publications, cataloging (including familiarity with AACR2 and MARC format), computer searching and collection development. Full-time, tenure-track, faculty positions. Rank of Senior Assistant Librarian or Associate Librarian. Salary range is $\$ 31,680-\$ 55,548$. Reappointment, promotion, and tenure require evidence of continuing professional development. Desired starting date: October 1, 1989. Application date: The Appointment Committee will begin screening applications on September 1, 1989. Applications will be taken until the positions are filled but should be received as early as possible to ensure full consideration. Please submit letter of application with resume and names of at least three references to: Gerald D. Palsson, Associate University Librarian for Administrative Services, Ref: GOV, San Diego State University Library, San Diego, CA 92182-0511. Please note on your application which position you are applying for. SDSU is an affirmative action, equal opportunity, Title IX employer.

LIBRARIAN. Head, Catalog Department. Supervises and coordinates a cataloging unit with a staff of 6 FTE paraprofessionals and two professionals including head. The unit processes over 10,000 volumes per year. Other duties include responsibilities as a subject bibliographer. Required: Master's degree in library science from an ALA-accredited school and a minimum of four years of progressively responsible professional technical services experience; strong background in supervision and management; knowledge of LC classification, LCSH, AACR2, and MARC formats; demonstrated communication and interpersonal relations skills. Preferred: Some experience with an online catalog. Position is twelve-month, tenure-track, TIAA/CREF or state retirement. Salary is $\$ 26,000-\$ 29,000$. Hunter Library has an annual materials budget of approximately $\$ 700,000$, contains over 350,000 volumes, and has a staff of 14 professionals and 25 paraprofessionals. Western Carolina University, with two other state universities, has formed the Western North Carolina Library Network, which shares an LS/2000 OPAC/circulation system. Send letter of application, resume, official transcripts, and names and telephone numbers of three references to: Sharon Kimble, Search Committee, Hunter Library, Western Carolina University, Cullowhee, NC 28723. Preference given to applications received by September 1, 1989. Western Carolina University is one of the sixteen senior institutions of the University of North Carolina and an affirmative action, equal opportunity employer. The University is located between the Great Smoky Mountains and the Blue Ridge Mountains, 55 miles west of Asheville, North Carolina. 
LIBRARIAN FOR NORTH PACIFIC STUDIES. Bibliographic/subject specialist for North Pacific Studies Center, Oregon Historical Society. Responsibilities: analyzes subject strengths and needs for collection development; functions as reference liaison librarian between library and the North Pacific Studies Center staff; serves as coordinator of library services to researchers, resident and visiting scholars, and staff. Qualifications: Library degree; knowledge of cataloging principals; knowledge of and experience with OCLC database or other bibliographic utility; reading skill (with help of dictionary) of Japanese, Korean, or Chinese, preferably Chinese language; knowledge of Pacific Northwest History and Pacific Rim countries desirable. Salary: $\$ 20,000$ to $\$ 25,000$ depending on experience. Excellent vacation and fringe benefits. Send letter of application and resume, including references, to: Oregon Historical Society, 1230 S.W. Park Ave., Portland, OR 97250, ATTN: L. W. Flannery. Phone: (503) 222-1741.

MAP LIBRARIAN (new position). Reports to the Head, Reference and Information Services. Responsible for managing the operations of the map collection located in the Hoskins branch library. The map collection contains over 350,000 maps. Primary responsibilities will include the provision of reference service for the unit, including database searching and bibliographic instruction, supervision of two full-time staff and student assistants, collection development, liaison with faculty, and assistance with cataloging and classification of cartographic materials. There will be a close liaison with the Documents/Microforms area. Required qualifications: ALA-accredited MLS degree; effective oral and written communication skills; a good public service attitude; and evidence of ability to work well with faculty, students, and staff. Must have minimum of two years professional (post-MLS) library experience in public services, preferably in an academic library. Library faculty must meet university requirements for promotion and tenure. Preferred qualifications: coursework in geography or a science, or experience with maps and a broad understanding of cartographic information sources. Supervisory experience. Experience with map cataloging. Reading knowledge of one or more foreign languages. Microcomputer experience. Tenure-track position. Twenty-four days annual leave, tuition remission, usual benefits. Assistant Professor rank. Salary $\$ 25,000$ minimum. Send letter of application, current resume, and names, addresses, and telephone numbers of three recent references to: Jill Keally, Personnel Librarian, The University of Tennessee Library, 1015 Volunteer Boulevard, Knoxville, TN 37996-1000. Review of applications will begin September 1, 1989, and will continue until the position is filled. UTK is an EEO, Affirmative Action, Title IX, Section 504 Employer.

MINORITY INTERNSHIP. Miami University has a strong commitment to affirmative action and is actively seeking to increase minority representation in all areas of the University. The University Libraries Minority Internship Program is one component of the Libraries' overall affirmative action plan and is intended to increase the representation of minority librarians at Miami and to further the growth and development of minority librarians within the profession. This newly established program is designed to assist a recent library school graduate in making a successful transition to academic librarianship. The Miami University Libraries are committed to introduce and orient the recent minority graduate to the complexities of academic librarianship in a rapidly changing environment. The one- or two-year internship will provide the opportunity for hands-on experience in all areas of the University Libraries' operations, including public, technical, and administrative services. Actual assignments will be made based on interests of the individual and needs of the Libraries. This internship will report to the Dean and University Librarian. Qualifications: An MLS from an ALA-accredited library school (degree requirements must be fulfilled by August 1989 for appointment in 
August/September or December 1989 for appointment in January 1990). Members of minority groups are the focus of this program. The Miami University Libraries contain over 1.4 million volumes, have an extensive collection of government documents and microforms, and subscribe to over 12,000 serials. They serve 800 teaching and research faculty, 15,000 undergraduates, and 1,000 graduate students. The library has 34 professional librarians and 55 support staff. Miami University is a highly selective institution, located in Oxford, $\mathrm{OH} 35$ miles northwest of Cincinnati. Benefits include Blue Cross/Blue Shield, major medical, disability, dental, and term life insurances all paid by the University. Public employee retirement system. Salary level is $\$ 23,000$. Submit letter of application, resume, and names, telephone numbers, and addresses of three professional references to: Judith A. Sessions, Dean and University Librarian, Miami University, Oxford, $\mathrm{OH}$ 45056. Preliminary screening of applications will begin August 1, 1989. Miami University is an equal opportunity employer.

PROJECT MANAGER, Dartmouth College Information System, Dartmouth College Libraries and Dartmouth College Computing Services. Responsibilities: Directs and manages the design, development, and implementation of the Dartmouth College Information System (DCIS), a large software development project whose goal is to provide easy access over local and national networks to an expanding universe of information through a workstation-based user interface. Oversees a project team of several software developers; plans the direction and pace of technical development and innovation for DCIS and assures timely completion of components. Promotes DCIS on and off campus and facilitates the integration of DCIS into the instructional and research activities of the College. Coordinates vendor relationships and fundraising for the DCIS Project. The project is expected initially to take 3 years and is funded through foundation and corporation grants. Qualifications: Must have 3 to 5 years of experience in technical areas (applications development, systems programming, systems analysis) including some management responsibilities, or the equivalent. Experience in an academic environment and a Ph.D. would be assets. Familiarity with library operations, information retrieval, and database management technologies is highly desirable. Must have demonstrable oral and written communication skills. Salary and Benefits: Salary commensurate with background and experience with a minimum of $\$ 45,000.22$ days vacation; TIAA/CREF; paid major medical, hospital, and dental insurance; liberal sick leave and disability programs; assistance with moving expenses. Applications: Resume review will begin August 1, 1989. Send resume to: Phyllis Jaynes, Director of Library User Services, 115 Baker Library, Dartmouth College, Hanover, NH 03755. Dartmouth College is an AA, EEO, M/F employer. Minority candidates are encouraged to apply.

SYSTEMS INFORMATION SPECIALIST. A major Wall Street law firm using Unix Operating System is seeking an individual responsible for maintaining the online card catalog, developing and implementing a serial check-in system (including routing and binding and billing modules); troubleshooting computer problems; setting up databases using the in-house system for the firm's work products. Requirements: 3 plus years of experience in setting up and converting datafiles, working knowledge of programming especially "C" language, familiarity with OCLC and/or other utilities, and experience in setting up integrated systems. Must be able to work independently. Salary $\$ 40,000+$, excellent fringe benefits. Please send resume and a detailed description of experience to: Nuchine Nobari, Davis Polk \& Wardwell, One Chase Manhattan Plaza, New York, NY 10005.

REFERENCE/INSTRUCTION LIBRARIAN. For general reference, library instruction, science collection development, and faculty liaison to science 
department. Will also include online and CD-ROM database searching in science. Required: MLS from an ALA-accredited institution, academic background in life sciences or experience in science reference, training or experience in online or CD-ROM searching, excellent communication skills. Preferred: Academic degree in science, teaching experience, computer skills. Position available August 1, 1989. Salary: \$22,000-\$26,000. Application deadline: Applications will be accepted until the position is filled, but for maximum consideration applications must be received by July 21 . Send letters of application, resume, transcripts, and names of 3 references to: Anne Commerton, Director, Penfield Library, State University College, Oswego, NY 13126. SUNY Oswego is an equal opportunity employer. Women, minority persons, handicapped persons, and Vietnam veterans are encouraged to apply.

REFERENCE LIBRARIAN for small private career-oriented liberal arts college. ALA/MLS. Responsibilities include desk service, library instruction, online searching, government publications, and collection development. Share day, evening, and Sunday hours. 12-month, tenure-track position. Salary $\$ 20,000$. Excellent benefits. Send resume and three references to: Susan M. Campbell, Library Director, Schmidt Library, York College of Pennsylvania, Country Club Road, York, PA 17405-3426. Deadline: August 15, 1989.

REFERENCE LIBRARIAN. Join a team of eight librarians to develop and deliver library service for the 1990s. Responsibilities include general reference, online searching, CD-ROM services, and collection development. ALAaccredited MLS and the ability to communicate effectively both orally and in writing required; reference and online searching experience desirable. Salary $\$ 22,000-\$ 24,000$. Excellent fringe benefits, including 22 days of vacation annually. Available: September 2, 1989. Application deadline: August 21, 1989. Indiana University Northwest is a 4,600-student campus of Indiana University. Its proximity to industrialized population centers, rural areas, and national park land in Indiana, and to Chicago and its environs, provides varied residential, educational, and recreational opportunities. Send resume and the names of three references to: Robert Moran, Jr., Director of Library Services, Indiana University Northwest, 3400 Broadway, Gary, IN 46408. An equal opportunity employer.

REFERENCE LIBRARIAN, Science Specialty. Reports to the Head of the Reference Department. Responsible for providing general reference to students and faculty in the main library and reference (including chemistry, pharmacy, and medicine) in the Science Library. Responsible for collection development in assigned subject area. Responsible for some database searching. Requirements: ALA-accredited MLS. Prefer a science degree or a substantial number of science courses taken, preferably in chemistry. Demonstrated listening, oral, and written communication skills; proven ability to work independently and cooperatively with patrons, colleagues, and staff. Experience with online systems desirable. Reference experience in an academic or science library is preferred but recent graduates are encouraged to apply. UOP is an independent coeducational institution with 3,800 students and 275 faculty. UOP offers more than 50 major programs in most of the traditional areas of the physical and life sciences, the humanities, and the social and behavioral sciences. Three doctoral programs are offered in chemistry, pharmacy, and education. Programs are also offered by the six professional schools including: Conservatory of Music, Business and Public Administration, Education, Engineering, International Studies, and Pharmacy. The library holds 355,000 volumes and receives 3,120 current subscriptions. Rank and Salary: Appointment at the rank of assistant professor. Salary of $\$ 20,000$ minimum (depending on qualifications and experience). Twenty-four days of vacation, 11 holidays, TIAA/CREF, and generous benefits. Applications will be accepted until position is filled, but those 
received before September 15 will receive first consideration. Send letter of application, resume, and the names, addresses, and phone numbers of three current references to: Jessica A. Marshall, Associate Dean, University of the Pacific, University Libraries, 3601 Pacific Ave., Stockton, CA 95211. UOP is an equal-opportunity, affirmative-action employer.

SERIALS LIBRARIAN (reopened). Responsibilities: Reports to the Acquisitions Librarian and assists in all aspects of coordinating and integrating serials with acquisitions and cataloging. Supervises the Processing Supervisor, two and one half Acquisitions Department support staff as pertains to their serials duties, and part-time students. Does original and copy cataloging of periodical titles using OCLC. Coordinates the review of gift and duplicate exchange lists for periodicals. Supervises the updating of the library's holdings in a cooperative OCLC union list of serials. Supervises the use of Innovacq for serials check-in and binding. Responsible for the bibliographic control among the library's manual and automated files. Responsible for collection development in assigned subject area. Requirements: ALA-accredited MLS. Ability to manage the complexities of serials; cataloging experience with an online system, preferably OCLC, required; knowledge of current theory and practice of bibliographic control; proven skills in problem solving; listening, oral, and written communication skills; proven ability to work independently and cooperatively with patrons and colleagues. Recent graduates will be considered if they have applicable experience in a para-professional position. UOP is an independent coeducational institution with 3,800 students and 275 faculty. UOP offers more than 50 major programs in most of the traditional areas of the physical and life sciences, the humanities, and the social and behavioral sciences. Programs are also offered by the six professional schools including: Conservatory of Music, Business and Public Administration, Education, Engineering, International Studies, and Pharmacy. Three doctoral programs are offered in chemistry, pharmacy, and education. The library holds 355,000 volumes and receives 3,120 current subscriptions. Rank and Salary: Appointment at assistant or associate rank with a salary of $\$ 25,000$ minimum (depending on qualifications and experience). Twenty-four days of vacation, 11 holidays, TIAA/CREF, and generous benefits. Applications will be accepted until position is filled, but those received before September 15, 1989 will receive first consideration. Send letter of application, resume, and the names, addresses, and phone numbers of three current references to: Jessica A. Marshall, Associate Dean, University Libraries, University of the Pacific, 3601 Pacific Ave., Stockton, CA 95211. UOP is an equal-opportunity, affirmative-action employer.

SOCIAL SCIENCE LIBRARIAN. Tenure-track, 10 1/2-month faculty appointment available immediately. Responsible for library liaison with all Social Science Departments. Duties: collection development, general reference, DIALOG searching, maintenance of federal documents and university archives. Qualifications: MSLS from an ALA-accredited program, second master's in Social Science or History, ability to work with students and faculty and meet university requirements for tenure. Excellent benefits; salary $\$ 23,000-\$ 26,000$, dependent on background and experience. Send letter of application; resume; names, addresses, and telephone numbers of three references to: Clayton Highum, Illinois Wesleyan University Library, 201 E. University St., Bloomington, IL 61702. IWU is an equal opportunity employer.

TECHNICAL SERVICES LIBRARIAN. Austin Presbyterian Theological Seminary seeks a Technical Services Librarian to assume primary responsibility for cataloging and serials control. Duties will also include overseeing acquisition processing, maintaining authority file and supervising student assistants. As the library becomes more fully automated, an additional 
responsibility will be overseeing the online public catalog maintenance. Qualifications: ALA-accredited MLS degree, two years cataloging experience; knowledge of LC classification, subject headings, and MARC record formats; ability to use OCLC and other bibliographic utility. Preference will be given to persons who have technical services experience in an academic library, who possess knowledge about online automated systems, and/or microcomputer applications in libraries and who have graduate degrees in Religious Studies. Salary: $\$ 22,000-\$ 26,000$. Excellent benefits. Send applications with references or write for more information to: Valerie R. Hotchkiss, Stitt Librarian, Austin Presbyterian Theological Seminary, 100 East 27th Street, Austin, TX 78705-5797. Application deadline is August 1, 1989. AA/EEO.

UNIVERSITY LIBRARIAN, Georgetown University, Washington, D.C. Georgetown University invites applications and nominations of highly qualified candidates for the position of University Librarian of its main campus library system consisting of a central facility and three branches currently housing over one and a quarter million volumes. The University Librarian manages a staff of 145 FTE and a total budget of over $\$ 5.2$ million. An integrated automated computer system (GEAC) (Online catalog, circulation, acquisitions, and serials) is operational. The Library, a member of ARL, is an active participant in the Washington Research Library Consortium. Candidates should demonstrate proven administrative ability in a large academic library system; experience with information and computer technology; strong commitment to the teaching, research, and service missions of the University; the ability to communicate effectively; a knowledge of modern management practices as applied to libraries; a commitment to regional resource sharing; experience in library fundraising; an understanding of and commitment to affirmative action and equal opportunity; and commitment to the goals and objectives of Georgetown as a Jesuit, Catholic institution of higher education. The University Librarian has primary responsibility for budget, facilities, planning, library services, collection development, fundraising, local library cooperation, personnel, and library automation. Requirements are an ALA-accredited Master's degree. An additional advanced degree in an appropriate subject field is highly desirable. Candidates should demonstrate a record of increasing administrative responsibility and success in an academic research library. Appointment to be effective, if possible, by February 1, 1990, otherwise by July 1, 1990. Applicants should send a resume and the names of at least three references by October 30 , 1989. Applications, nominations, and questions should be directed to: Search Committee for University Librarian, C/O Marie-Helene Gibney, Office of the Provost, Georgetown University, Washington, DC 20057; (202) 687-6400. Georgetown University is an equal opportunity, affirmative action employer.

COORDINATOR OF PUBLIC SERVICES/HEAD REFERENCE LIBRARIAN. The University of the South seeks a creative, energetic, peopleoriented librarian to coordinate and supervise Reference, Circulation, Interlibrary Loans, Archives and Special Collections, and Non-Print Services in duPont Library. Reports to University Librarian and serves on Library Administrative Cabinet. Required: ALA-accredited MLS, five years professional academic library experience with significant reference service; three years progressively responsible supervisory experience in libraries; demonstrated ability to work effectively with patrons and staff; excellent interpersonal skills; ability to plan, develop, and implement effective public service program. Preferred second graduate degree; experience with computer technology related to library services. Position available: July 1, 1989. Salary Range: $\$ 25,000-\$ 31,900$; excellent benefits; applications will be accepted until position is filled. Send letter of application, resume, and three references to: David Kearley, University Librarian, University of the South, Sewanee, TN 37375. 
EOE. Minorities are encouraged to apply.

TWO POSITIONS. Collection Development Librarian. We need an experienced librarian to plan and carry out our collection development program. Responsibilities include: establish measures of collection strengths and weaknesses; formulate collection development plans for academic subjects; evaluate changing academic programs for collection impact; reassess ongoing programs for collection needs; serve as liaison to other academic libraries in local Consortium in planning cooperative collection development programs. Qualifications include: ALA minimum 5 years experience, 2 of which must have been in collection development; ability to work effectively with administrators, faculty, and library staff. Salary is $\$ 30,000$. Cataloger. Performs original descriptive cataloging and classification for materials in all formats, subjects, including name and subject authority work. Should have thorough knowledge of AACR2, LCSH, LC classification, MARC, and other standard cataloging tools. OCLC experience desirable. One year professional cataloging experience required. Salary is $\$ 22,000$. Each position requires an MLS degree from an ALA-accredited school. Excellent fringe benefits including faculty status. Send resume by August 30th, 1989 to: James DeLancey, Georgetown University Library, P.O. Box 37445, Washington, DC 20013. Georgetown University is an Affirmative Action, Equal Opportunity Employer.

REFERENCE LIBRARIAN. The University of Northern Iowa has an immediate opening. The librarian in this position participates in a full range of reference duties including reference desk service, bibliographic instruction, computerized searching, and related assignments. Also serves as bibliographer in Library's collection management program. One of $71 / 2$ general reference positions. ALA/MLS and good interpersonal, written, and oral communications skills required. Reference coursework or experience required. A strong academic background in the humanities (excluding art and music) preferred. A second master's degree or equivalent required for tenure. Work year consists of academic year-including summer session-plus two weeks. Off approximately eight weeks per year. TIAA/CREF retirement plan and excellent fringe benefits. Salary: $\$ 21,500$ minimum. Application deadline: screening of applications will begin on September 1, 1989 and continue until the position is filled. Send letter of application, resume, transcripts, and names of three references to: Gerald Peterson, Chair, Search Committee, Donald 0. Rod Library, University of Northern Iowa, Cedar Falls, Iowa 50613. UNI is an equal opportunity educator and employer with a comprehensive plan for affirmative action.

SYSTEMS COORDINATOR for DRA installation, Lamar University. Circulation, and Acquisitions operational. Responsibilities include: implementing additional functions and software releases; facilitating communications between the library, the vendor, and the campus computer center; training staff; planning for all aspects of library automation. Qualifications: Required: ALA-accredited M.L.S.; experience in library systems management; excellent communication and interpersonal skills. Preferred: Experience in academic libraries, DRA, microcomputers, networking, interlibrary cooperation, and multi-library systems. Salary and Benefits: In the low 30s, dependent upon qualifications and experience. Twelve-month appointment, faculty rank and status. Send letter of application, resume, and names of at least three references to: Juanita Weisel, Search Committee Chair, Lamar University, Gray Library, Box 10021, Beaumont, TX 77710. Applications will be received until position is filled; however, for first consideration, submit by August 15, 1989. Lamar University Beaumont is an equal opportunity, affirmative action employer. 


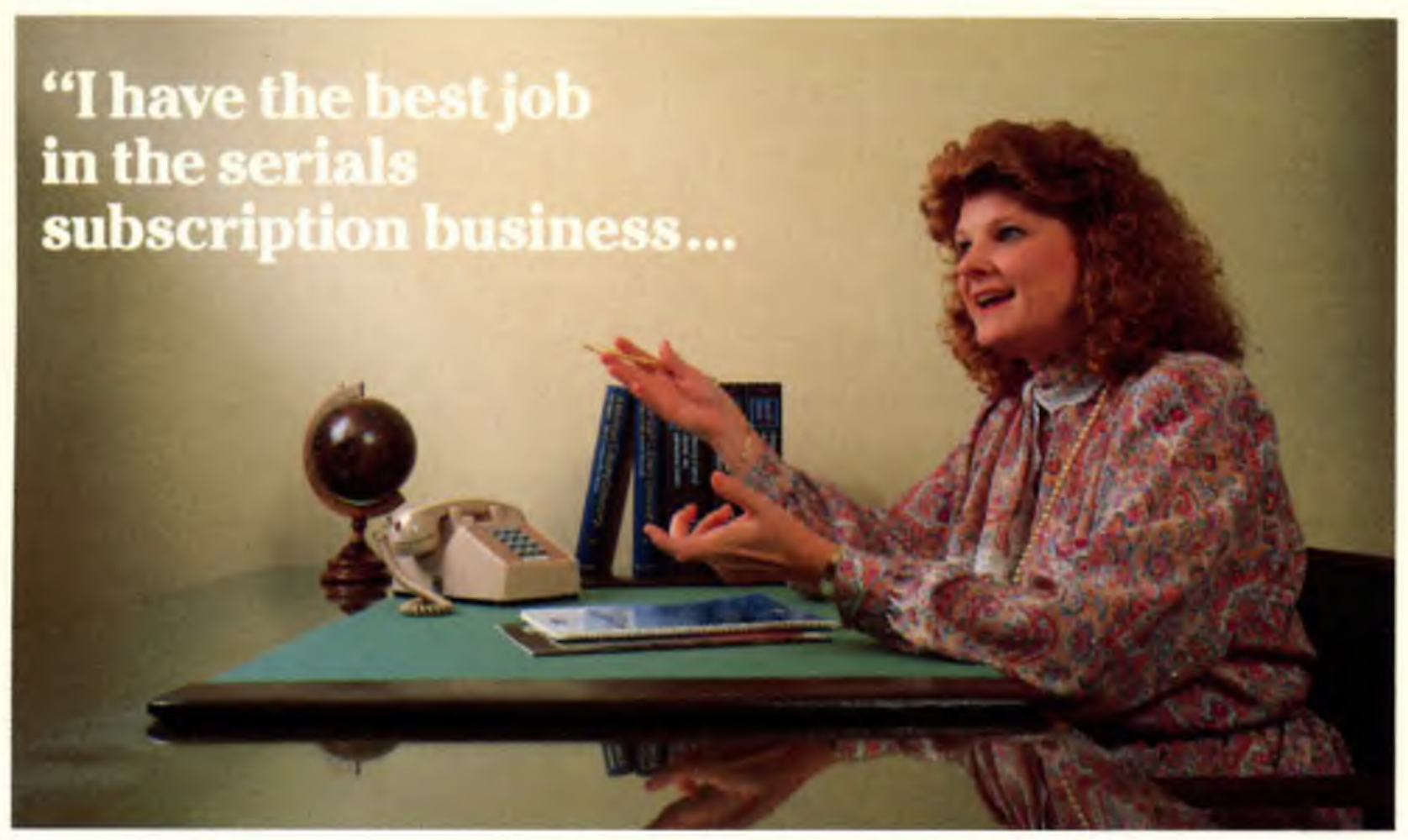

\section{because it offers so many opportunities for service to my library colleagues.}

"I spent 16 years in an academic library where I experienced firsthand the complexities of serials management, the challenges of collection development and the great demands placed on academic librarians. At EBSCO l've found a significant way to put that experience to work for our customers.

"I'm an Account Services Manager, a position that's unique to EBSCO in the serials subscription business. It's my job to see that you get all the help you need from EBSCO to manage your serials responsibilities effectively. So I listen ... I advise ... and I solve problems.

"Like my counterparts in EBSCO Regional Offices across the country, I work with the other members of your serials support group-the EBSCO Sales Representative, General Manager and Customer Service Representative-to ensure that the routine aspects of your subscription program are handled promptly and efficiently. But l'm also available to help with the more sophisticated, non-routine needs you might have-like collection development reports, budget planning reports, inservice training seminars, reviews of services provided and of others available through EBSCO ... whatever your special needs may be."

Lee Ketcham, MLS Account Services Manager

At EBSCO, we think librarians deserve qualified personnel who know and understand the challenges they face. Isn't that what you expect from a professional subscription agency?

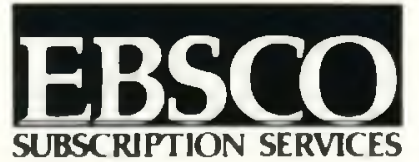

International Headquarters

P.O. Box $1943 \bullet$ Birmingham, AL 35201

(205) 991-6600 


\section{a new quarterly journal growing out of today's urgent needs for help}

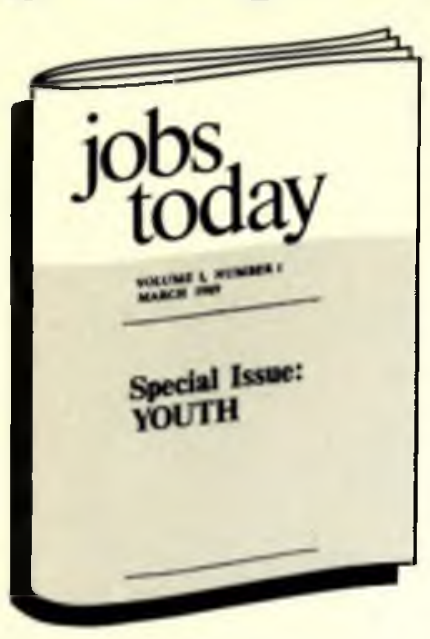

for people

looking for jobs.

\section{for employers \\ interested in tapping sources of skilled or trainable workers.}

\section{for government and private agencies} concerned with developments in employment.

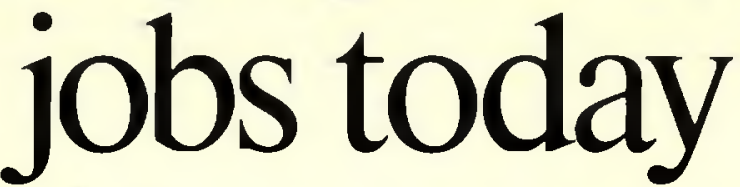

Current developments concerning employment, particularly of the young, the elderly, women, and the disabled. Subscription rate: $\$ 48.00$ per year; $\$ 15$ per issue.

In a land of plenty we have by the millions: disillusioned young people who never expect to hold jobs

bewildered seniors cast adrift by unwanted retirement ... women, minorities, and handicapped victimized by job discrimination in many forms. Yet, millions of job openings go unfilled.

Jobs Today, just launched in 1989, is already on its way to making a number of dents in this vast problem.

In Issue No. 1, Youth, Jean K. Elder reports on great strides being made by Youth 2000 , a project of the U.S. Office of Human Development Services whose goals are twofold: providing jobs for every qualified teenager .... and making sure that millions of young people, currently "disconnected" from society, are qualified by the year 2000 . Other articles discuss Wall Street, banking, the military and other fields, with practical guidance on preparing forand getting-jobs in these areas.

College and non-college alternatives-using library resources in job hunting; resumes and interviews that land jobs; holiday employment as preparation for the real thing-all are typical of the 21 articles by experts on the firing line of youth employment.
Issue No. 2, Seniors, focuses on problems and opportunities of older workers. Retirees seeking rewarding full- or part-time jobs .... seniors who do not wish to retire . . . elderly people who prefer to work at home ... . and employers who are open to using the skills of workers with long experience

all will find useful guidelines in these pages. Here it all is - from practical tips for workers on résumés (functional, not chronological!) and interviews, to detailed reports for employers on the methods other companies use to tap this vast labor resource.

Cumulative index by general fields. precise subjects, and by people, places, and organizations makes all material add up, issue by issue, to a unique encyclopedia of otherwise hard-to-find information.

Selected bibliographies identity major sources for detailed information on subjects dealt with in the articles.

Coming issues will focus on employment problems and opportunities of women. handicapped, minorities, at-home entrepreneurs, and disadvantaged people.

\section{New Reference on British Literati}

\section{THE BLOOMSBURY ICONOGRAPHY}

Edited by Elizabeth P. Richardson. Illus. 384 pages. Published by St. Paul's Bibliographies, Winchester, England, 1989. Distributed in North America exclusively by Omnigraphics. $\$ 84.00$

This new index brings together and classifies printed portraits, sketches, and photos of Lytton Strachey, Virginia and Leonard Woolf. E. M. Forster. Roger Fry and Clive Bell. and others who made up Londori's distnguished Bloomsbury people, places, and things relating to this famous group which flourished in the first third of the century at Bloomsbury Square, the center of London's cultural activities.

This index to pictures of the group, their tamilies, triends, and terrain will be a uselul reference source for researchers in art, photography, crafts and decoration. social history, and bibliography There are nearly 4,000 pictures from some 400 sources

Phonames build goodwill faster

than any other tool that costs so little

\section{PHONAMES DICTIONARY}

Introduction by Faith and Ross Eckler. 664 pages. Over 33,000 entries. $\$ 350,00$

Many of your patrons may be passing up millions of dollars worth of tree advertising. Even your library may be missing out on a valuable goodwill device.

But you can now help end this waste with this unusual new Phonames Dictionary. Phonames are a tool you see at work everyday Ads on radio and TV. in newspapers and magarnes, on billboards. in the Yellow Pages, say ... Dial BUTCHER for meat
. For vacafion planning, dial I-IRAVEL . . . For car care, call SERVICE . . . For burglary protection, dial 4-SAFETY... For a locksmith, call LOCKMAN

Just ask the law firm that owns the phone number, 529-9377. how much they'd take for their combination that spells "LAWYERS" Ask Amtrak what value they place on the number they advertise nationwide: "Call 1-800-USA-RAIL."

Of course, nobody gets such lucky numbers by luck They require planning to take the guesswork out of this important planning. Omnigraphics offers the world's first directory that provides all the guidance one needs to create Phonames that "sell" a company, institution, product, service, or idea

Just open Phonames Dictionary and you'll see page after page of numbers - with the WORDS they can spell on any telephone dial. Over 33,000 combinations altogether!

All items on 60-day approval.

$10 \%$ discount on standing orders.

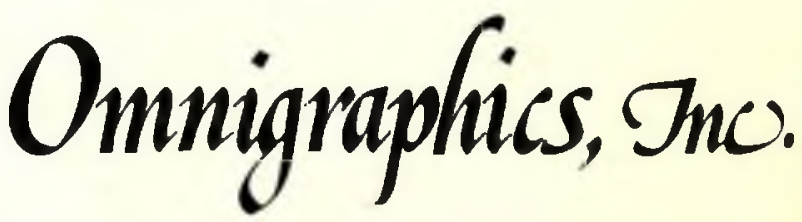

Penobscot Building - Detroit, MI 48226

Fax:313-961-1383 - Toll-free phone: 800-234-1340 